\title{
Measurement and Modeling of External Radiation During 1985 from LAMPF Emissions
}

\author{
Brent M. Bowen \\ William A. Olsen \\ Ili Chen \\ Donald M. Van Etten
}

\section{DISCLAIMER}

\begin{abstract}
This report was prepared as an account of work sponsored by an agency of the United States Government. Neither the United States Government nor any agency thereof, nor any of their employees, makes any warranty, express or implied, or assumes any legal liability or responsibility for the accuracy, completeness, or usefulness of any information, apparatus, product, or process disclosed, or represents that its use would not infringe privately owned rights. Reference herein to any specific commercial product, process, or service by trade name, trademark. manufarturer, or otherwise does not necessarily constitute or imply its endorsement, recommendation, or favoring by the United States Government or any agency thereof. The views and opinions of authors expressed herein do not necessarily state or reflect those of the United States Government or any agency thereof.
\end{abstract}

\section{MASTER}

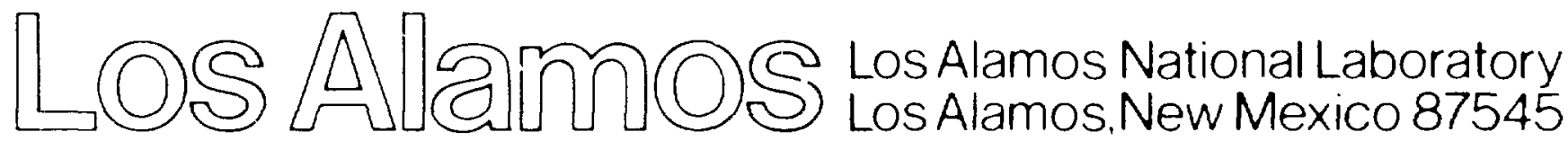




\title{
MEASUREMENT AND MODELING OF EXTERNAL, RADIATION DURING; 1985 FROM LAMPF EMISSIONS
}

\author{
by \\ Brent M. Bowen, William A. Otsen, \\ Ili Chen, and Donald M. Van Fitten
}

\begin{abstract}
An array of three portable, pressurized ionization chambers (PICs) continued to measure external radiation levels during 1985 caused by radionuclides emitted from the Los A lamos Meson Physics Facility (LAMPF). The monitoring was at the closest offsite Iocation, averaging $800 \mathrm{~m}$ north and northeast of the source, just across a 120 -m-deep canyon. A Gaussian-type atmospheric dispersion model, using onsite meteorological and stack release data, was tested during this study. A more complex linite model, which takes into account the contribution of radiation at a receptor from different locations of the passing plume, was also tested.

Monitoring results indicate that, as in 1984, a persistent wind up the Rio Grande Valley during the evening and early morning hours is largely responsible for causing the highest external radiation levels to occur to the northeast and north-northeast of LAMPF. Daytime winds are more southerly, transporting more radionuclides toward the north and north-northeast. However, because of increased turbulent mixing during the day, external . adiation levels are generally much less during the day than at night. External radiation levels during 1985 show approximately a $75 \%$ reduction over 1984 levels. This resulted from a similar percentage reduction in LAMPF emissions caused by newly implemented emission controls.

Comparison of predicted and measured daily external radiation levels indicates a high degree of correlation. The model also gives accurate estimates of measured concentrations over longer time periods. Comparison of predicted and measured hourly values indicates that the model generally tends to overpredict during the day and underpredict at night.
\end{abstract}

\section{INTRODUCTION}

The Los Alamos Meson Physics Facility (LAMPF) is an 800-million-electron-volt, 1-milliampere-intensity linear proton accelerator used for studying nuclear interactions with subatomic particles at relativistic velocities.
Routine operation of the accelerator results in formation of short-lived activation products, primarily in the beam stop section of LAMPF. These activation products, which are principally the radioisotopes ${ }^{11} \mathrm{C}, 13 \mathrm{~N}$, and $15 \mathrm{O}$, are monitored and vented to the atmosphere, increasing the external radiation at the Laboratory boundary. 
During 1985, approximately 127,000 curies (Ci) of activation products were released from LAMPF. This proluces a total measured radiation exposure of 11.4 mrem at the Laboratory boundary north-northeast of the LAMPF stack, which resulted in an estimated maximum individual dose of $7.3 \mathrm{mrcm}^{*}$ (ESG 1986) or $29 \%$ of the Environmental Protection Agency (EPA) 25-mrem radiacion prolccuion standard (EPA 1985).

The 1985 emissions represent over an $80 \%$ reduction from those of 1984 , when $734,000 \mathrm{Ci}$ were reicased. The reduction in emissions was primarily accomplished by holding the radioisotopes before telease through the stack, allowing the short half-life radionuclides to decay at the production point. The large emissions decrease was responsible for nearly a $75 \%$ reduction in radiation levels at the north-northeast boundary from those in 1984, when the total radiation exposure and estimated maximum individual dose werc 44 and $31 \mathrm{mrem}$, respectively (ESG 1985).

Offsite radiation exposure levels from LAMPF opcrations have been routinely monitored since 1977. A network of thermoluminescent dosimeters (TLDs) was placed at the Laboratory boundary affected by LAMPF emissions. In 1982, a pressurized ionization chamber (PIC) was placed at the fenceline location of the maximum external radiation level (Bowen 1982). This instrument has the capability of monitoring short-term radiation levels and shor-tern external radiation changes from the passing LAMPF plume. The PIC measurements are used as a baseline to compare with predictions given by a Gaussian-type atmospheric dispersion model that uses onsite meteorological and release data.

This study presents both monitoring and modeling results of external radiation levels at three locations during 1985 caused by LAMPF emissions. Measured radiation exposures are presented for all three iocations during an 86-day period. Predicled daily levels using a simple Gaussian r.ıodel are compared with daily measured values. Predicted values using a more complex finite model are also examined. Average, hourly predicted and measured extemal radiation levels are compared with each other and in relation to average winds. Accuracy of the model is tested for different times of the day, windspeeds,

\footnotetext{
*This dose is from exposures that exclude contributions from background radiation (cosmic, terrestrial, global fallout, and self-irradiation sources). The doses calculated are those believed to be possible to individuals under realistic exposure conditions.
}

horizontal wind, and vertical wind. Cumulative external radiation during the 86-day period, as measured by the PICs, is compared with both the sum of 24-hour estimates and the scasonal form of the model using average winds. Annual model predictions are also compared with TLD measurements.

\section{BACKGROUND}

The Los Alamos National Laboratory is localed on the Pajarito Plateau on the eastern flanks of the Jemez Mountains (Fig. 1). The Sangre de Cristo Mountains lie nearly $70 \mathrm{~km}$ to the east. The Rio Grande Valley runs north-northeast to south-southwest between the two mountain ranges. The plateau slopes downward to the cast from the base of the Jemez Mountains (approximately $2500 \mathrm{~m}$ above sea level or MSL) to the Rio Grande $(\sim 17(0) \mathrm{MSL})$ over a distance of $25 \mathrm{~km}$. There also are numerous alternating "finger" mesas and canyons running along the slope line of the plateau. The canyons are 50-100 $\mathrm{m}$ deep and 100-200 $\mathrm{m}$ wide. LAMPF is located on a mesa top just south of Los Alamos Canyon.

The LAMPF stack is located about $700 \mathrm{~m}$ south of the closest Laboratory boundary location across the Los Alamos Canyon. Thrce short-lived, gaseous radioactive air activation products, $15 \mathrm{O}, 11 \mathrm{C}$, and $13 \mathrm{~N}$, account for virtually all dcwnwind radiation levels. Several other radioactive gases are released; however, they are much less important because of either extremely short half-lives of a few seconds or the extremely small quantities. Because of positron annihilation from radionuclide decay, ph̀oton radiation is emitted from the plume of gases as it travels downwind from the stack. However, the total amnunt of plume radiation decreases with time (downwind distarice) as the radionuclides decay. Some characteristics of these three radioactive gases are shown in Table 1 . Note that the three gases account for $96 \%$ of the rodioactivity of the effluent gas, with ${ }^{11} \mathrm{C}$ and 150 being the largest sources of radiation. However, the percentage of 150 remaining at $800 \mathrm{~m}$ (average distance of monitors from stack) varies dramatically with windspeed (travel time) because of its short half-life. The contribution of 150 to the total plume radioactivity at the Laboratory boundary is direculy proportional to windspeed. The contribution of radioactivity from 150 at $800 \mathrm{~m}$ downwind is nearly equal to that from $13 \mathrm{~N}$ with a $6 \mathrm{~m} / \mathrm{s}$ wind, while the radioactivity from 150 is slightly greater than that from $13 \mathrm{~N}$ at greater windspeeds. The largest contribution of radioactivity comes from ${ }^{11} \mathrm{C}$ 


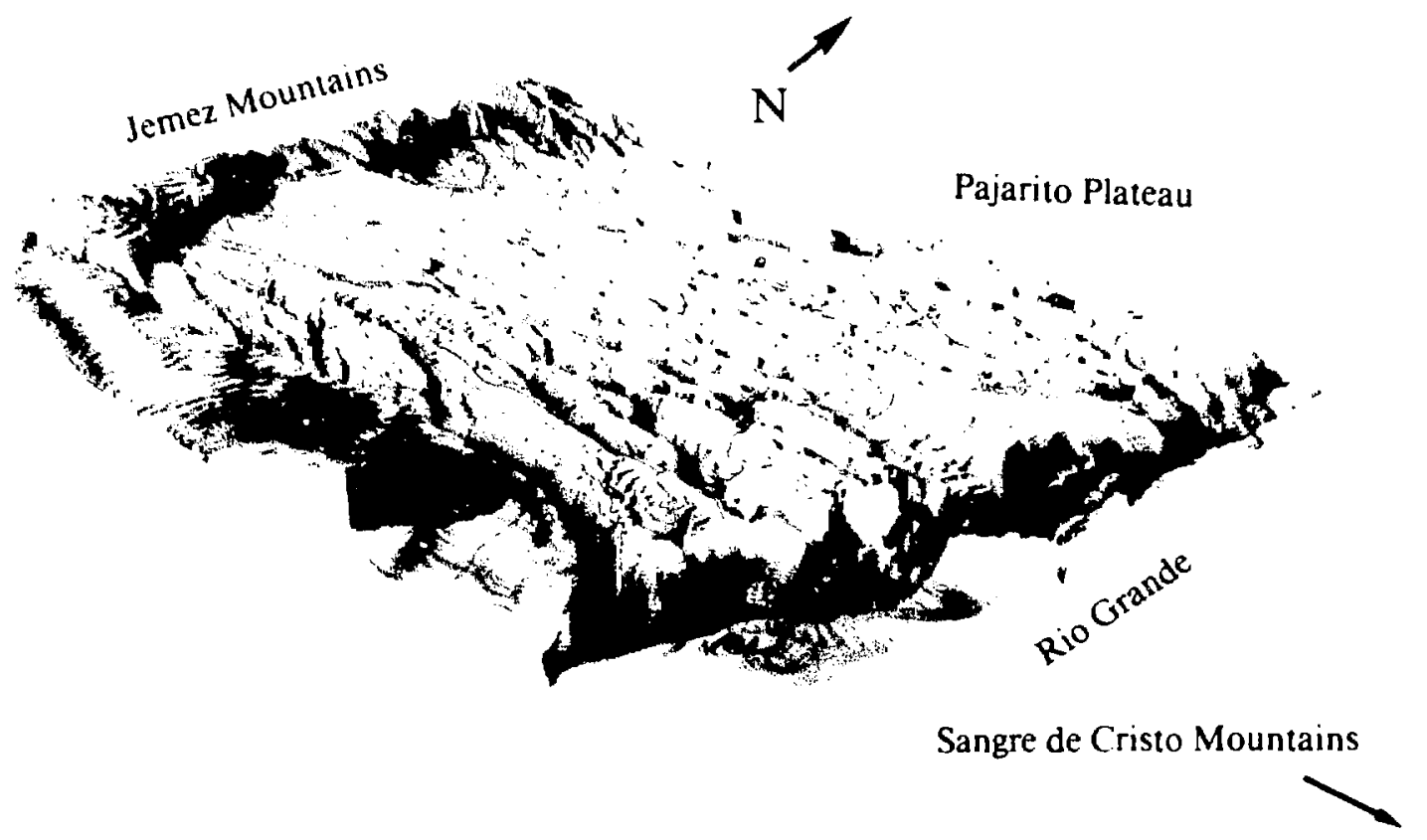

Fig. 1. Regional location of Los Alamos.

at all windspeeds, because it is the predominant radionuclide at release and it has the longest half-life.

Table I shows that total radioactivity in the plume varies greatly with the windspecd. With stronger windspecds, fewer radioactive atoms have decayed at a distance downwind; however, stronger winds enhance dilution of the gases, causing lower concentrations downwind. With increasing windspecd, the "dilution factor" mitigates some of the radionuclide "decay factor." For example, assuming the average release rate of $21 \mathrm{Ci} / \mathrm{h}(20$ $\mathrm{Ci} / \mathrm{h}$ resuluing from the three gases) during $1985,11.5$ $\mathrm{Ci} / \mathrm{h}$ or $57 \%$ of the original amouni is estimated to remain in the plume $800 \mathrm{~m}$ downwind with a $3 \mathrm{~m} / \mathrm{s}$ windspecd. At twice the windspeed, $6 \mathrm{~m} / \mathrm{s}$, the amount remaining increases to $14 \mathrm{Ci} / \mathrm{h}$, or $71 \%$ of the original amount. However, the dilution is twice as great with a $6 \mathrm{~m} / \mathrm{s}$ wind as it is for a $3 \mathrm{~m} / \mathrm{s}$ wind. Therefore, over the typical windspeed range, the increased dilution at higher windspeeds more than offsets any increase in radiation from shorter travel times, resulting in a decrease in radiation levels. Also, windspecd can affect the stability, and in turn, indirecty affect plume concentrations and resulting gamma radiation.

Table I. Release Data of the Three Primary Radioactive Gases and Amounts of Radioactivity Remaining a $800 \mathrm{~m}$ Downwind During 1985

\begin{tabular}{|c|c|c|c|c|c|c|c|}
\hline \multirow{2}{*}{$\begin{array}{l}\text { Radioactive } \\
\text { Gases }\end{array}$} & \multirow[b]{2}{*}{$\%$} & \multirow{2}{*}{$\begin{array}{l}\text { Release } \\
\text { Rate } \\
(\mathrm{Ci} / \mathrm{h})\end{array}$} & \multirow{2}{*}{$\begin{array}{c}\mathrm{T} 1 / 2 \\
(\mathrm{~s})\end{array}$} & \multicolumn{4}{|c|}{$\begin{array}{l}1 / 4 \text { Remaining at } 800 \mathrm{~m} \\
\text { for Different Windspeeds }\end{array}$} \\
\hline & & & & $1(\mathrm{~m} / \mathrm{s})$ & $3(\mathrm{~m} / \mathrm{s})$ & $6(\mathrm{~m} / \mathrm{s})$ & $10(\mathrm{~m} / \mathrm{s})$ \\
\hline${ }^{11} \mathrm{C}$ & 38 & 8.0 & 1230 & 64 & 86 & 93 & 96 \\
\hline${ }^{15} \mathrm{O}$ & 36 & 7.5 & 123 & 1 & 22 & 47 & 64 \\
\hline${ }^{13} \mathrm{~N}$ & 22 & 4.5 & 598 & 40 & 74 & 86 & 91 \\
\hline Total & $\overline{96}$ & $\overline{20.0}$ & $\bar{\ldots}$ & $\overline{33}$ & $\overline{57}$ & $\overline{71}$ & $\overline{80}$ \\
\hline
\end{tabular}

${ }^{a}$ Denotes average relcase ate over 7-month operation period. 
The mix of the threce prinary radionuclide gases curng 1985 was quite different than in 1984 (Table II). Changes were made to the exhaust system in 1985 to reduce the emissions. The exhaust gas containing the radionu iide's is held for a lime before being released througn the stack. The radionuclides are reduced by decaly hefore entering the atmosphere. A comparison of Tables I and II shows that the relative fraction of the shorter half-life 150 was $50 \%$ lower in 1985 than in 1984. Conversely, relative fractions of longer half-lived $11 \mathrm{C}$ and $13 \mathrm{~N}$ are considerably higher during 1985 than during 1984. The larger percentage of "longer" half-lives in the effluent during 1985 is expected to allow a larger percentage of the radinactivity released to reach the Laboratory boundary. For example, with a very light wind of $1 \mathrm{~m} / \mathrm{s}, 33 \%$ of the radioactivity should remain at 800 in downwind during 1985 compared with $13 \%$ during 1984 . This percentage difference narrow's with increasing windspeed. For a nure lypical windspeed of $3 \mathrm{~m} / \mathrm{s}, 68 \%$ more of a unit curie would have remained at the boundary $(800 \mathrm{~m})$ during 1985 than in 1984. The larger percentage of longer half-lives is expected to slightly mitigate the reduction in total curies. Based on an $83 \%$ reduction in emission from $198+$ to 1985 , a $75 \%$ reduction in radioactivity from 1984 to 1985 is expected at a downwind distance of $800 \mathrm{~m}$ with a windspecd of $4 \mathrm{~m} / \mathrm{s}$. This reduction would increase with increasing windspeed.

\section{NETHODOLOGY}

\section{A. Siting and Instrumentation}

1. LAMPF Releases. The study area is shown in Fig. 2. The LAMPF slack is $30 \mathrm{~m}$ high and has a di- ameter at the top of $0.9 \mathrm{~m}$. A 5 -liter, air-ioniration instrument is used to monitor the radioactive gases entering the stack. A voltage is recorded, which is proportional to the tolal stack gas radionuclide air concentrations in $\mathrm{Ci} / \mathrm{m}^{3}$. The release rate is then calculated by multiplying the air concentration by the stack flow. Stack velocity is measured continuously by an anemometer placed half way up the stack and by periodic stack tests.

2. External Radiation Monitoring. Three PICs continued to monitor real-time external gamma radiation to air during 1985 at the nearest offsite boundary across the Los Alamos Canyon. The instruments are located at azimuths of $0^{\circ}$ (north), $22^{\circ}$ (north-northeast), and $45^{\circ}$ (norheast) of the LAMPF stack.

The PiCs are located 700, 750, and $915 \mathrm{~m}$ north, north-northeast, and northeast, respectively, from the stack. Each instrument uses a modified Reuter-Stokes high-pressure ionization chamber. A special electronics package was made to provide greater accuracy for the range of measurements (Van Etten 1987). A weatherproof metal box, containing a battery pack, a microprocessor-controlled datalogger, and solid-state data storage module is required for each PIC. A solar collector located on the top of each box maintains charge on the batterics. The dataloggers provide onsite summarization of radiation data. Because of the weather-induced temperature extremes that $\propto$ ccur inside the boxes, a solidstatc data storage module is used to store the data rather than a cassette recorder.

An array of 12 lithium fluoride TLD stations routincly monitors long-term gamma doses. The network is also located along State Road 4 and extends from the north-northwest to the northeast of the LAMPF stack.

Table 11. Release Data of the Three Primary Radioactive Gases and Amounts of Radioactivity Remaining at $800 \mathrm{~m}$ Downwind During 1984

\begin{tabular}{|c|c|c|c|c|c|c|c|}
\hline \multirow{2}{*}{$\begin{array}{c}\text { Radioactive } \\
\text { Gases }\end{array}$} & \multirow[b]{2}{*}{$\%$} & \multirow{2}{*}{$\begin{array}{c}\text { Release }^{a} \\
\text { Rate } \\
(\mathrm{Ci} / \mathrm{h})\end{array}$} & \multirow{2}{*}{$\begin{array}{c}\mathrm{T} 1 / 2 \\
(\mathrm{~s})\end{array}$} & \multicolumn{4}{|c|}{$\begin{array}{l}\% \text { Remaining at } 800 \mathrm{~m} \\
\text { for Different Windspeeds }\end{array}$} \\
\hline & & & & $1(\mathrm{~m} / \mathrm{s})$ & $3(\mathrm{~m} / \mathrm{s})$ & $6(\mathrm{~m} / \mathrm{s})$ & $10(\mathrm{~m} / \mathrm{s})$ \\
\hline${ }^{11} \mathrm{C}$ & 16 & 27 & 1230 & 64 & 86 & 93 & 96 \\
\hline${ }^{15} \mathrm{O}$ & 72 & 122 & 123 & 1 & 22 & 47 & 64 \\
\hline${ }^{13} \mathrm{~N}$ & 4 & 7 & 598 & 40 & 74 & 86 & 91 \\
\hline Toral & $\overline{92}$ & 156 & $\cdots$ & 13 & 34 & 55 & 69 \\
\hline
\end{tabular}

${ }^{a}$ Denotes average relcase rate over 7 -month operation period. 
STAIF ROAD 4

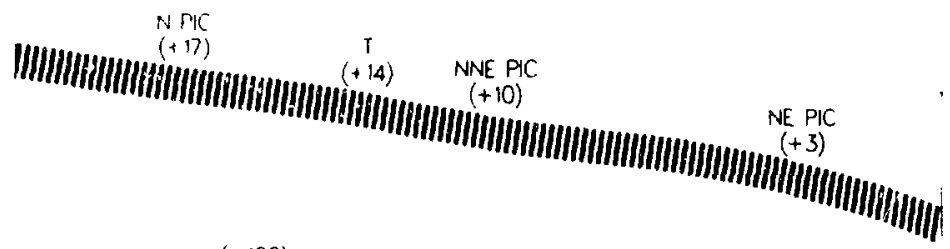

$(-120)$

LOS ALAMOS CANYON

$(-130)$

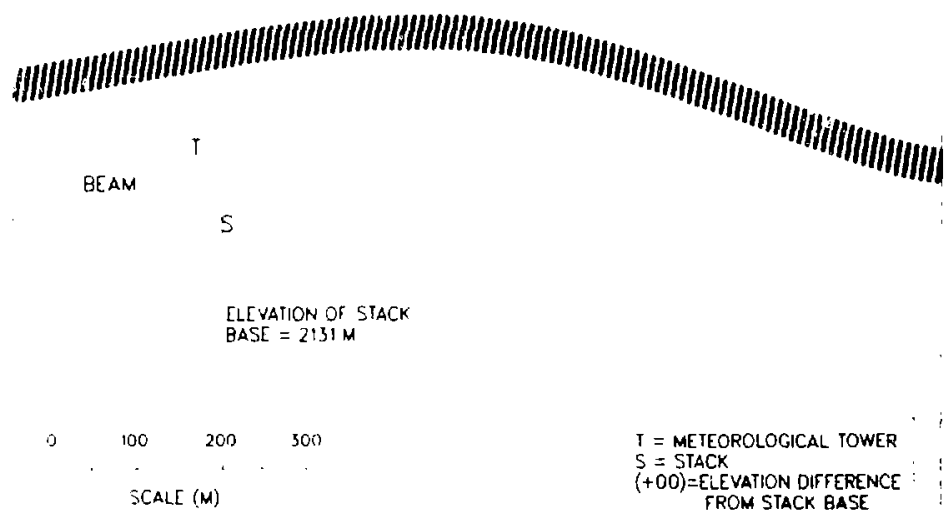

Fig. 2. Map of study area.

TLD stutions are approximatcly $70 \mathrm{~m}$ apart. Another TLD network unaffected by Laboratory operations provides the background absorbed external radiation dose levels.

3. Meteorology. The East Gate metcorological tower that provided data for this study is located between the north and north-northeast PICs at a distance of $725 \mathrm{~m}$ and a bearing of $12^{\circ}$ from the LAMPF stack (Fig. 2). Horizontal winds are measured at levels of 1.3, 4.0, and $12.0 \mathrm{~m}$ and verical winds at 4.0 and $12.0 \mathrm{~m}$. Propeller vanes were installed at all levels in September of 1985 to measurc wind direction and specd. Prior to this, wind di- rection and specd were measured by two horizontal, orthogonal (U-V) propeller anemometers. Vertical velocity continues to be measured by a vertically oriented anemometer. Thermistors equipped with blower aspirators measure temperature at heights of 1.3 and $12.0 \mathrm{~m}$. Solar radiation, relative humidity, and rainfall are also recorded at this sitc.

Another tower is located about $100 \mathrm{~m}$ to the northnorthwest of the stack on the south side of Los Alamos Canyon. A three-way, orthogonal (U-V.W) propeller, anemoneter sy'stem measures the horizontal and vertical wind at a height of $26 \mathrm{~m}$. 
I3. Data

1. Data Gathering. All data (except TLDs) were collected by dataloggers. One datalogger collected the East Gate tower data on State Road 4. Another processed the source-term data and LAMPF tower-wind data. Dataloggers also collect the data at each PIC. The dataloggers provide 15-minute averages for all the data and standard deviations for the wind data.

2. Determination of Radiation Background. Extemal radiation measured by the PICs included background levels as well as the levels caused by LAMPF cmissions. It was, therefore, necessary to estimate and subtract background levels from the total measured values. The daily background level at each PIC site was estimated by using total meastred values during times when the LAMPF plume was not affecting the sites. These periods were determined by scanning daily plots of the three PICs. A minimum of 12 "plume-frce" hours was desired to determine daily background. There frequently were periods of several day's when it was impossible to estimate background. During these periods, the closest day (before or after) on which a background level could be calculated was used.

The long-term background was determined by using absorbed doses measured by a remote TLD network that is located in an area unaffected by Laboratory emissions. This background was then subtracted from the total levels measured by the State Road 4 TLD network.

3. Uncertainty. Typical data ranges and uncertainty are listed in Table IIl. Most of the uncertainties of extemal radiation, stack gas radioactivity, and radionuclide fractions are usually within $\pm 10 \%$. However, stack velocity, which is dircclly related to stack release, has an uncerainty of $\pm 25 \%$ based on stack tests. Stack tests using Pitot cube probes have shown a large variability in the past, probably because of the relatively low stack velocitics. The anemometer placed in the stack shows a much smaller variability; however, it is difficult to know if it is representative of the entire stack cross section. Metcorological data uncertaintics secm modest except for the wind direction. Instrument uncertainties at the two sites plus the uncertainty caused by using two different wind measurement systems can be important, considering the angle between two adjacent PICs is only $22.5^{\circ}$. A wind direcuon crror of $5.110^{\circ}$ can shift a considerable amount of predicted external radiation levels from one PIC site to an adjacent site. Also, the wind direction can actually differ at the two sites because of local terrain and the height differences above the ground of the sensors.

\section{Resources}

Meteorological data from the two towers were used in this study. The East Gate tower is used routincly to supply data on weather conditions in that arca of Los Alamos. The LAMPF tower, which supplies only one level of wind data, is primarily maintained for this study. A datalogger also is in operation at LAMPF to collect metcorological tower and stack data. The ionization chamber that provides the stack release data is routincly maintained by the Accelerator Health Protection Group (HSE11). Ionization chamber calibration and stack gas composition data are supplicd by HSE-11.

\section{RESULTS AND DISCUSSION}

\section{A. Monitoring}

1. Short-Term External Radiation. Short-term radiation levels, caused by LAMPF emissions, can vary dramatically over shon time periods and distances. This is illustrated in Fig. 3 where plots of 15-minute radiation averages for the three PICs along with wind direction and specd and vertical velocity are shown for a day in 1985. Note the generally high external-radiation levels at the three sites during the first 8 hours of the day with light winds varying from southerly to southwesterly.* However, as the wind remains southerly from 0600-0800, a maxinum gamma exposure is evident at the north PIC. Meanwhile, the NNE PIC, located just $300 \mathrm{~m}$ cast, is only slightly affected by the plume, while the NE PIC shows no effect from the plume. The levels become rather low during the midday at all sites. Note how the plume appears to rotate clockwise along with the wind between 1600 and 1900 . The gamma exposure first peaks at the $N$ PIC, then at the NNE PIC, and finally at the NE PIC within a few hours, while the wind shifts from southerly to southwesterly. The reverse happens from 2100 to 2200 .

Gamma exposures remain relatively high at the NE and NNE PICs after 2100 because of southwest and south-southwesterly winds. Toul gamma exposures for

*Wind direction is defined as the direction from which the wind is blowing. 
Table 11I. Ranges and Uncertainty of Data Used in Study

\section{Data}

External Radiation

External Radiation

Stack Gas Radioactivity

Stack Velocity ( $\mathrm{Flow}$ )

at hal fway up stack

Stack Velocity ( $F($ ow)

at halfway up stack

Radionuclide Fractions

Wind Direction

(and standard deviation)

windspeed

Verticat windspeed

Temp. Difference

(12 $\mathrm{m}-1.3 \mathrm{~m})$

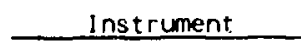

PIC

Ionization chamber

Pitot probes

Anemometer

Grab samples and

gamma spectrometry

Propeller anemometer.

$U-V$ wind system

$0-360^{\circ}$

$\left(2-45^{\circ}\right)$

$1-10 \mathrm{~m} / \mathrm{s}$

Propeller anemometer.

$U-V$ wind system

Vertically oriented

propelter

aspirated thermistuis

\section{Typical Range}

$10-50 \mu R / h r$

20-40 mR

(total for 3 months

(ocations)

$0-200 \mu \mathrm{ci} / \mathrm{m}^{3}$

$2.7 \cdot 4.5 \mathrm{~m} / \mathrm{s}$

$(10,500-17,500 \mathrm{CFM})$

$3.0-3.6 \mathrm{~m} / \mathrm{s}$

$(11,700-, 4,000$ (FM)

1985: $\begin{aligned} & { }^{11} \mathrm{c}-38 \% \\ & { }_{15} \mathrm{C}-36 \%\end{aligned}$

$13 \mathrm{~N} \cdot 22 \%$ and ave:aged for 12 $\pm 10 \%$ for

each radionuclide

Uncertainty

$\pm 2-6 \mu R / h r$

$\pm 1-2 \mathrm{mR}$

$\pm 10 \%$

$\pm 25 \%$

$+10 \%$ $\left( \pm 2^{\circ}\right)$

$\pm 0.3 \mathrm{~m} / \mathrm{s}$

$(-0.2)-(+1.5) \mathrm{m} / \mathrm{s}$

$(-3.0)-(+3.0)^{\circ} \mathrm{C}$
Comment

Also some uncertainty in dis $t$ nguishing LAMPF contribution from background
Range taken from stack tests performed over last 4 years

Additional uncertainty because placement of anemometer may not represent flow across the radius of the stack

The resulting uncertainty of radioactivity remaining at $800 \mathrm{~m}$ downwind ranges from $1-2 \%$ for strong winds $(10 \mathrm{~m} / \mathrm{s})$ to $\pm 10-15 \%$ for light winds ( $1-2 \mathrm{~ms})$

There is also uncertainty involved in using 2 different wind

measurement systems 


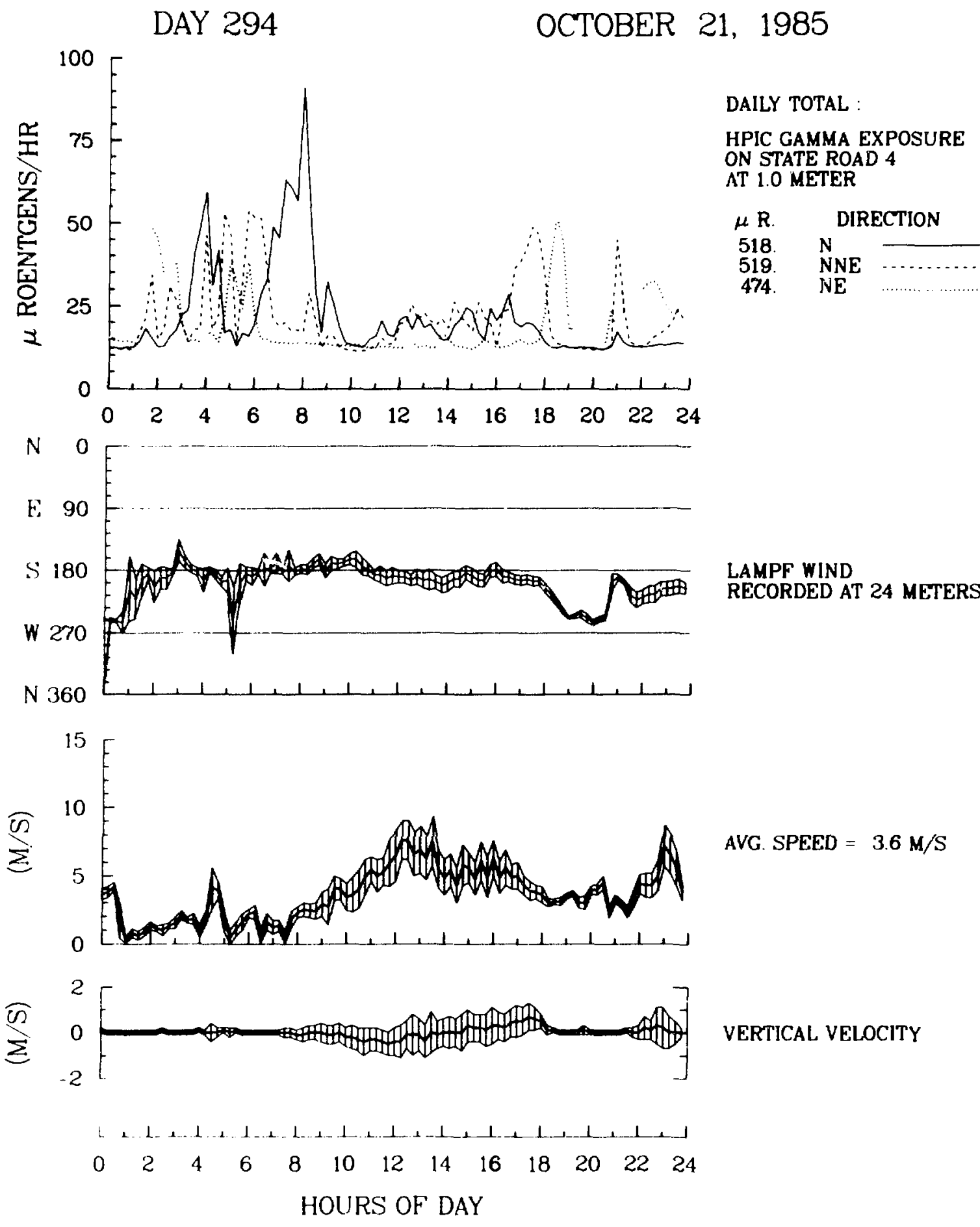

Fig. 3. Exiernal radiation and wind data during a day when the LAMPF plume is evident. 
the day at all three PICs are well above the typical background of approximately 300 microroentgens $(\mu \mathrm{R})$. This day it.dicates that the contribution from LAMPF is, actually less than the background contribution. Only several days during 1985 indicated contributions by LAMPF of over $300 \mu \mathrm{R}$ (total exposure $>600 \mu \mathrm{R}$ ). This contrasts with exposures during 1984, when LAMPF contributions frequently exceeded $300 \mu R$, with some daily contributions as high as $1500 \mu R$.

Two characteristics of the data on this particular day are also common on many other days. One is that the highest concentrations occur during the nighttime hours because of the decreased atmospheric turbulence at night. Observe that on this day, the standard deviations of windspeed and vertical velocity are greatly reduced during carly morning and much of the evening, when the gamma cxposures were greatest. On many days the standard deviation of wind direction is also considerably less during the night than the day. Even though winds are southcrly and south-southwesterly and directed toward the $\mathrm{N}$ and NNE PICs, these PICs indicate relatively low gamma levels because of increased vertical velocity ranges, and to a lesser extent (on this day), wind direction ranges. This day also has south-southwesterly and southwesterly winds during early morning and evening hours, and as a result, rclatively high radiation levels at the NE and NNE PIC. The pattem is seen repeatedly on other days.

2. Wind. The predominance of southerly through southwesterly winds in shown by East Gate wind roses in Fig. 4. These wind roses represent wind data for 86 days during 1985 on which data were available from all PICs and both towers. This limited period is representative of annual winds. A maximum frequency of winds is spread rather evenly over the southeast through south-southwest. About $45 \%$ of the daytime winds come from these directions. Much of the high frequency of the southeasterly and southerly winds results from a thermally driven upslope wind that occurs on days with sunshine and light, large-scalc winds. Winds are most often south-southwcsuly through southwesterly during the evening hours, with fewer southerly winds. Much of the high frequency of southwesterly and south-southwesterly winds is from the Rio Grande Valley channeling winds. Because predominant, large-scale winds are southerly, local winds flow along the orientation of the Valley and become southwestly and south-southwesterly. The channeling occurs more frequently at night when the vertical mixing is at a minimum. The south-southwestly and southwesterly winds account for $30 \%$ of all winds at night. The stable, low-level atmosphere prevents exchange of higher-level winds, thereby preserving the channeled flow.

Also, a secondary northeast wind maximum frequently occurs, especially during the morning hours. Some of these winds are possibly caused by channeling of winds down the Rio Grande Valley.

The frequency of winds from the south through southwest during 1985 appeared to have changed from that of 1984 (Fig. 5), although the general pattern of winds remaincd similar. Note that the southerly wind frequency increased during the daytime in 1985, while fewer southwestly and south-southwesterly winds occurred. The change in frequencies is even more dramatic at night, with the southwesterly wind frequency decreasing from $28 \%$ to $15 \%$. The south-soutiwesterly wind frequency increased somewhat, and, as during the daytime, southerly winds were more frequent. Annual wind roses were nearly identical for the years 1982-1984 before new wind sensors were installed.

Detection of subtle wind changes appears, however, to have been caused by replacement of orthogonal wind propellers (U-V) with a wind vane system. Correction factors must be applied to the propeller speeds of the U-V system to account for the cosine response associated with the angle of attack between the orientation of the propellers and the wind. The correction factors were determined and applied to the $U$ and $V$ propeller 15-minute averages instead of being applied to $U$ and $V$ instantaneously. This correction caused some slight errors in wind direction and a slight underestimation of wind speed.

This effect was also observed at the Occupational Health Laboratory (OHL), when the U-V wind system was replaced by the propeller system during early 1984 . As in the East Gate case, the general wind pattern appears similar using the two different wind sensor systems. But specific wind frequencies changed rather dramatically and average wind specd increased slightly after the replacement with the propeller anemometer. At OHL the annual wind roses were virtually the same for the years 1980-1983 until the wind system was replaced. There is rcason to believe, therefore, that changes of wind direction frequencies at East Gate from 1984-1985 were primarily because of the sensor changes, not the winds themselves.

LAMPF wind roses during the study period in 1985 are shown in Fig. 6. The winds are similar to those at East Gate (Fig. 4), although there are some noticeable 

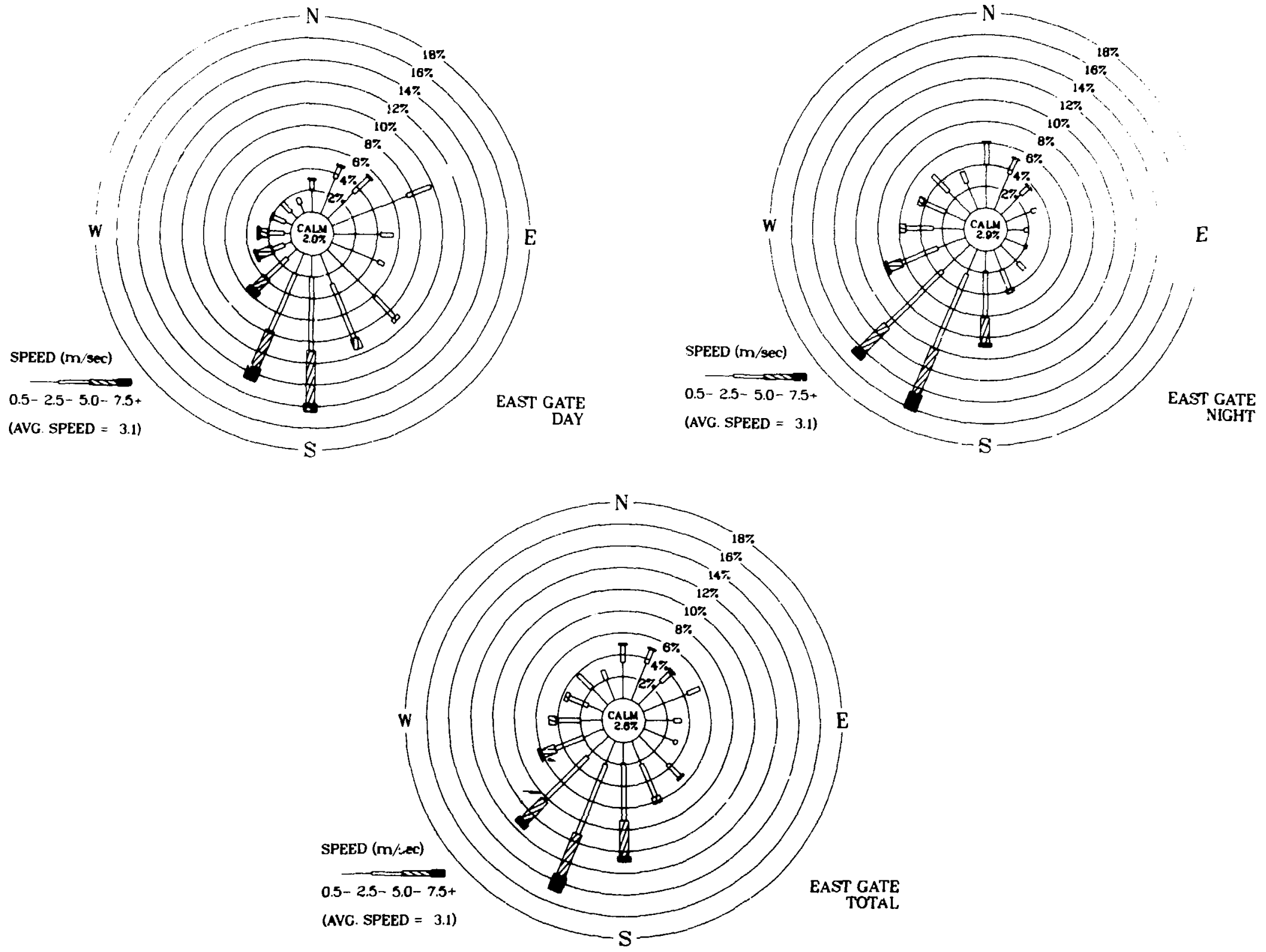

Fig. 4. Day, night, and total wind roses from East Gate at $12 \mathrm{~m}$ during an 86-day study period in 1985. 

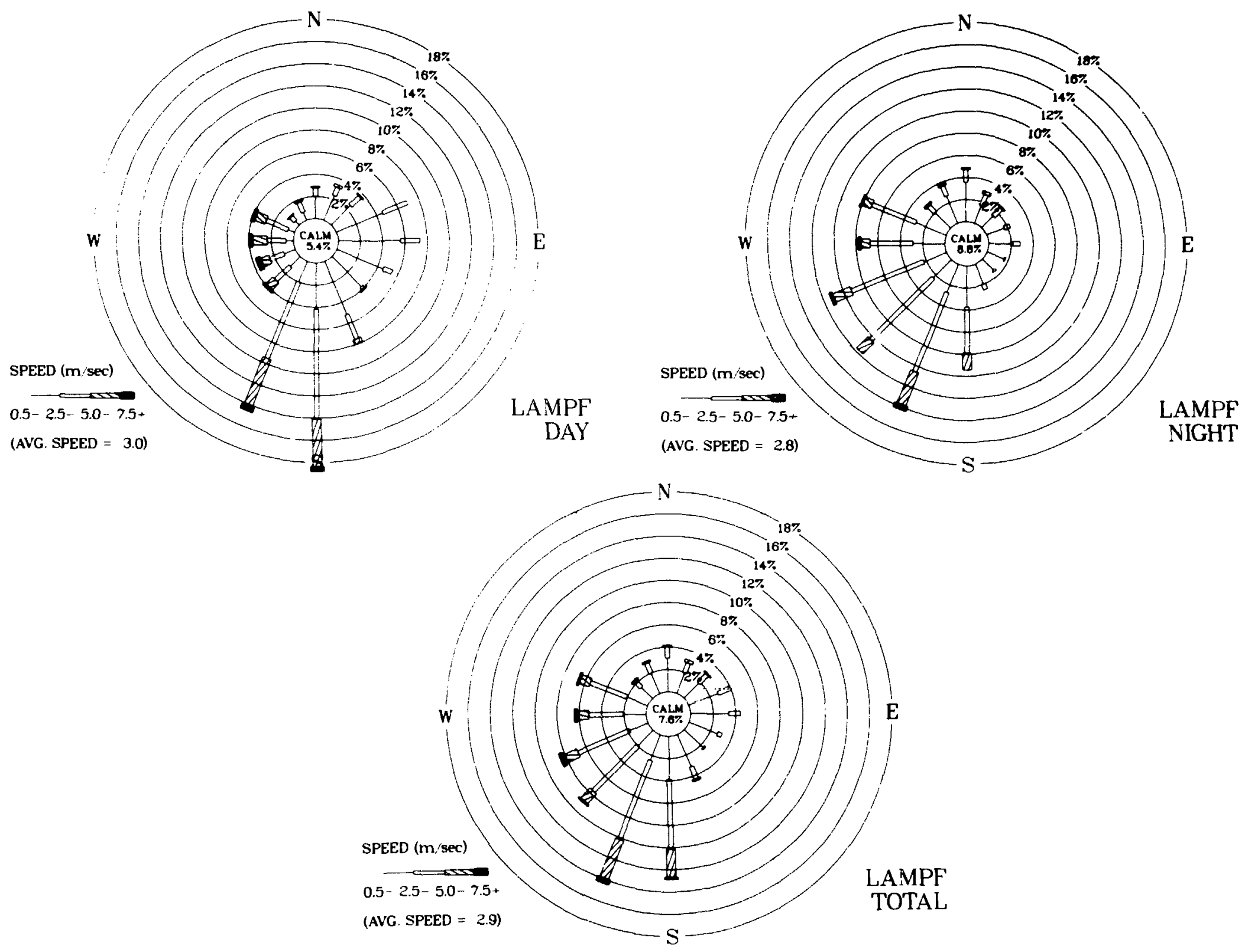

Fig. 6. Day, night, and total wind roses from LAMPF at $26 \mathrm{~m}$ during an 86-day stiddy period in 1985. 
differences. First, more south-southeast and southeasterly winds are apparent at East Gate than at LAMPF. The ground slopes downward more on the mesa just to the east of the East Gate tower than it does to the east of LAMPF. This may force more up-slope winds at East Gute.

Another daytime wind difference is the larger spike of east-northeast winds at East Gate than at LAMPF. One possible reason is that winds from this direction are very light, and the wind sensors at LAMPF register a less than $0.5 \mathrm{~m} / \mathrm{s}$ wind (calm) sometimes when East Gate sensors register winds greater than $0.5 \mathrm{~m} / \mathrm{s}$ wind from the eastnorthcast. Therefore, many of the light east-northeast winds at LAMPF are classified as calm winds. In fact, the total percentage of calm winds is much greater at LAMPF than at East Gate for both day and night. Winds appear to be quite similar at the sites at night, except that at LAMPF, there is a slight spike of winds from the westnordiwest, while there is not at East Gate. These winds are probubly downslope winds formad by radiational ground cooling at night. The mesa slopes more to the west of LAMPF than the mesa slopes to the west of East Catc. Also, there appear to be more northerly winds at East Gate than at LAMPF. However, this also may be because these winds are light, and there is a larger percentage of calm winds at LAMPF.

3. Average Measured External Radiation. The complex wind pattern causes large extemal radiation variations at the PIC sites from LAMPF emissions. Average hourly radiation lcvels resulting from LAMPF emissions for the 86-day study period are shown in Fig. 7. Both the highest and lowest hourly average occur at the VE PIC. The highest averages of nearly $7 \mu \mathrm{R} / \mathrm{h}$ occur during the early morning hours because of the high southwesterly wind frequency. Midday values are very low at the NE PIC because of the up-valley wind (Rio Grande) scarcity. The NNE PIC shows a similar, but more moderate daily radiation variation. The $\mathrm{N}$ PIC shows a relatively uniform average radiation level throughout the day. It must be stressed that increased daytime atmospheric mixing plays an important role in reducing radiation levels at all three sites. Also, we must remember that the NE PIC is located $20 \%$ further from the emission stack than are the other PICs. The levels would be nearly 10\% higher at the NE PIC if its downwind distance cqualed those of the other PICs.
4. Turbulence Parameters. Figure 8 shows the increased daytime mixing, which contains standard deviation histograms of horizontal wind $\left(\sigma_{\theta}\right)$ and vertical wind $\left(\sigma_{0}\right)$ by hour. The values of $\sigma_{\theta}$ are twice as large during the midday hours as they are during the late-night and early morning hours. The values of $\sigma_{0}$ are also larger during the day than at night. The diurnal variation of $\sigma_{\theta}$ is somewhat greater than that of $\sigma_{\phi}$.

5. Release Data. The daily variation in the LAMPF release rate also contributes somewhat to radiation variations. Average hourly release rates are shown in Fig. 9. The average release rate is at a slight minimum during the day, when routine LAMPF beam mairtenance is the greatest. The release rates used to calculate external radiation levels in the study are based on a stack velocity (midway) of $3.5 \mathrm{~m} / \mathrm{s}$ or a stack flow of $13,500 \mathrm{CFM}$. 'This corresponds to the average velocity indicated by the anemometer and is close to the stack test averages over the past 4 years.

6. Hourly Wind. A more detailed look at diurnal wind patterns is shown in a hourly frequency diagram in Fig. 10. Note that the up-valley wind starts to develop during the afternoon and becomes more frequent later in the evening and early morning hours. Scuthwesterly winds account for over $25 \%$ of all winds over a 5-hour period. These persistent winds are responsible for the maximum radiation levels at the NE PIC during the evening and early morning hours. By 0400 , the frequency of up-valley winds decreases while down-valiey winds become more important. By late moming, down-valley, northeastly winds account for over $20 \%$ of all winds. Also, upslope southeastly winds over the Pajarito Plateau are somewhat frequent during the late morning and early afternoon hours.

\section{B. Modeling}

1. Discussion and Equations. Two primary considerations in the modeling of radiation resulting from a plume are the receptor distance from the plume and the radiation intensity given off by the plume. These are in addition to the problem of estimating the downwind plume configuration and the radionuclide concentrations. A photon-emitting cloud with small dimensions compared with the distance the radiation travels is termed a finite 


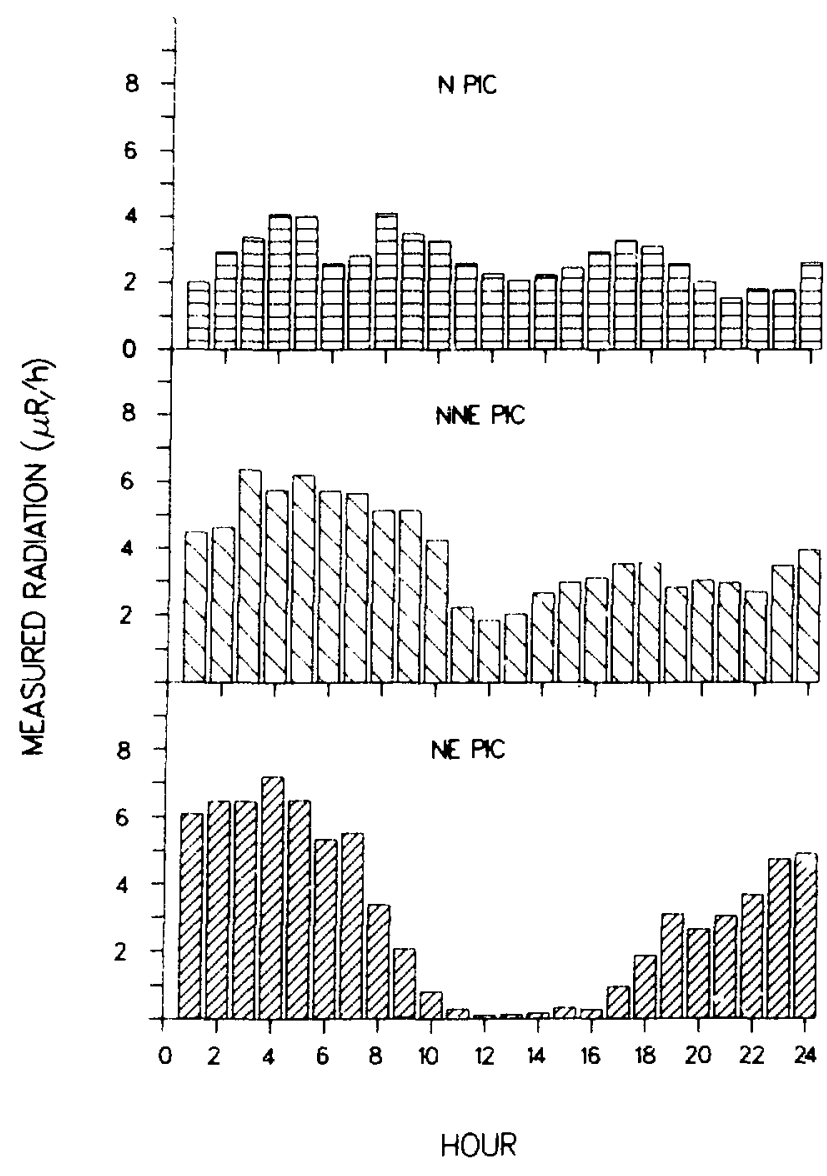

Fig. 7. Average hourly external radiation al three sites from LAMPF emissions during an 86-day study period.

cloud for modeling purposes. The following equation for finite clouds is suggested in Meteorology and Atomic Energy (Hcaly 1968):

$$
r_{i} D(x . y .())=\frac{0.1456 \mu \mu \mu_{n_{1}} \bar{E}_{n}\left(Q_{s}\left(I_{1}+k I_{2}\right)\right.}{\bar{T}}
$$

where

$$
\begin{aligned}
\gamma_{\mathrm{D}}= & \text { dose (rads) or exposure (roentgens); } \\
\mu & \text { total photon absorption to air coeffi- } \\
& \text { cient }(1 / \mathrm{m}) ; \\
= & \text { encrgy absorption cocfficient for } \\
& \text { photons in air }(1 / \mathrm{m}) ; \\
= & \text { average photon encrgy emitted at } \\
& \text { cach disintegration }(1.022 \mathrm{McV} / \\
& \text { Dis); }
\end{aligned}
$$
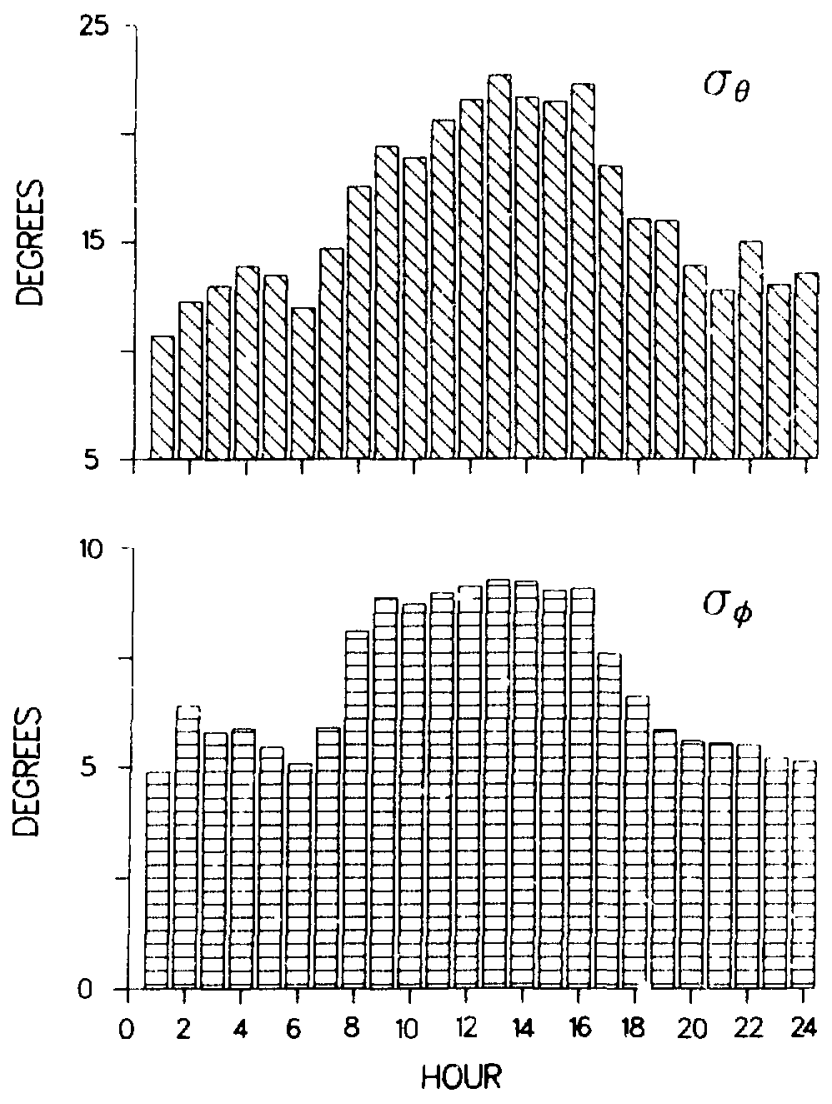

Fig. 8. Average hourly standard deviation of horizonial wind direction $\left(\sigma_{\theta}\right)$ and vertical wind $\left(\sigma_{\phi}\right)$ at East Gate during an 86-day sludy period.

$\mathrm{Q}_{\mathrm{x}} \quad=$ amount of source material remaining in a plume after a travel distance, $x(\mathrm{Ci})$;

$I_{1}+k I_{2}\left(\right.$ or $\left.I_{t}\right)=$ integrals accounting for the geometry of the plume and radiation from the plumes; and

$\overline{\mathrm{U}}=$ average wind $\operatorname{speed}(\mathrm{m} / \mathrm{s})$.

$E_{\gamma}$ is twice the LAMPF energy level of $0.511 \mathrm{MeV}$ because two photons are discharged for each disintegration. Also, the effect of lower air density because of the elcvation at Los Alamos ( $2140 \mathrm{~m} \mathrm{MSL})$ is accounted for by multiplying $\gamma D$ by 1.3 . Note that the integrals $I_{1}$ and $I_{2}$ used in this model must be determined hy chart or by a computer routine. These integrals are used to account for photon radiation travel away from the plume. Healy suggests using this finite cloud model when the plume spread 


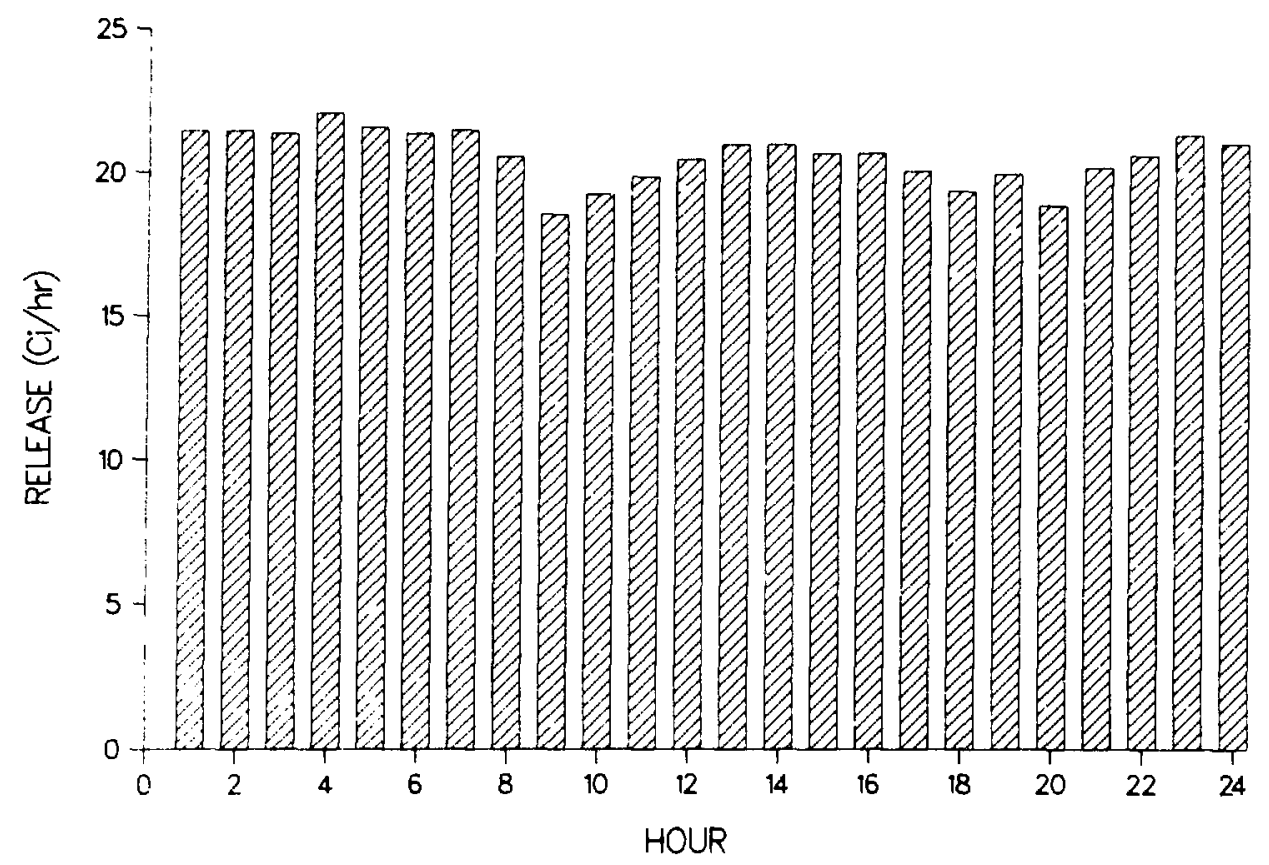

Fig. 9. Average emissions release rate from LAMPF during an 86 day study pericd.

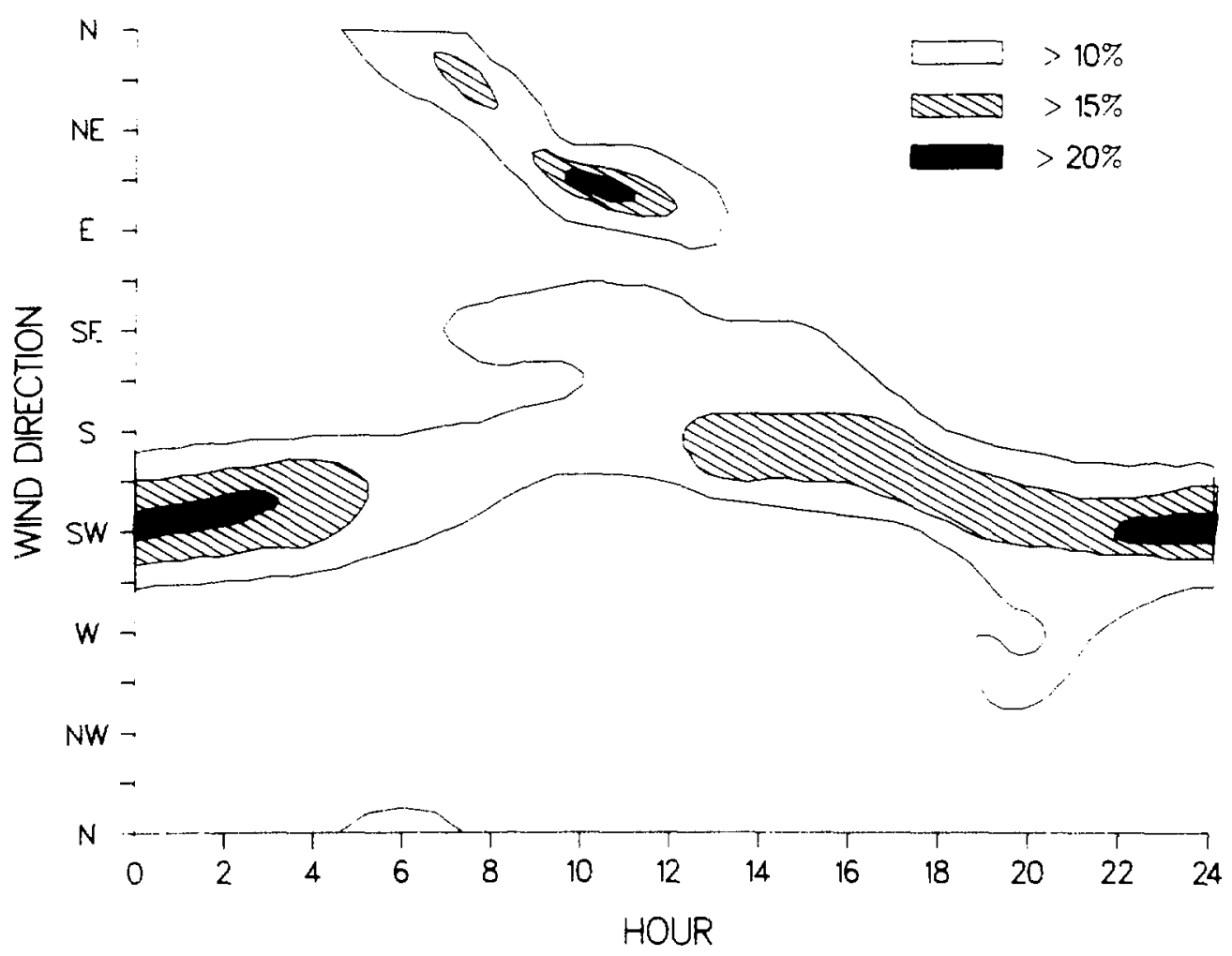

Fig. 10. Hourly wind direction frequency diagram for East Gate during an B6-day study period. 
standard deviation $(\sigma)$ is less than $1 / \mu(1 / \mu$ is approximatcly $120 \mathrm{~m}$ considering the photon energy of LAMPF emissions and the density of air at Los Alamos). The calculated $\sigma$ (geometric mean of $\sigma_{y}$ and $\sigma_{z}$ ) at $800 \mathrm{~m}$ downwind cquals $60 \mathrm{~m}$.

A much simpler infinite cloud model can be used for photon plumes at relatively large downwind distances. The following model for infinite clouds is taken from Mcteorology and Alomic Energy (Healy 1968):

$$
\gamma D=0.157 \bar{E}_{i}
$$

where $\chi$ is the radionuclide concentration $\left(\mathrm{Ci} / \mathrm{m}^{3}\right)$. This equation can be used during equilibrium or near-equilibrium conditions when just as much energy absorption per unit volume occurs as energy release per unit volume. This equation is directly proportional to $\chi$. Because $\chi$ is relatively casy to determine by using the Gaussian dispersion model, the infinite model is much wasier to calculate than is the finite model.

Healy suggests that Eq. 2 be reduced by a factor of 0.5 for the ground-level case. This is because a groundlevel receptor only receives radiation from half of the idealized cloud or plume. The equation becomes:

$$
i D=0.23 E_{,},
$$

The ground-level form of the Gaussian dispersion equation was used:

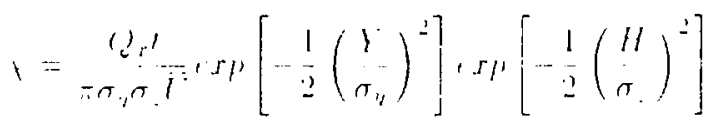

where

$$
\begin{array}{ll}
\chi & =\text { air concentration in } \mathrm{Ci} / \mathrm{m}^{3}, \\
\mathrm{Q}_{x}{ }^{\prime} & =\text { effective release ratc }(\mathrm{Ci} / \mathrm{s}), \\
\sigma_{y}, \sigma_{z} & =\text { dispersion cocfficients in the crosswind } \\
& \text { and vertical dircctions }(\mathrm{m}), \\
\mathrm{Y} & =\text { distance from plume centerline }(\mathrm{m}), \\
\frac{11}{\mathrm{G}} & =\text { effective stack release height }(\mathrm{m}), \text { and } \\
& =\text { average wind speed }(\mathrm{m} / \mathrm{s}) .
\end{array}
$$

For long-term integrated concentrations, the following form of the Gaussian dispersion equation was used:

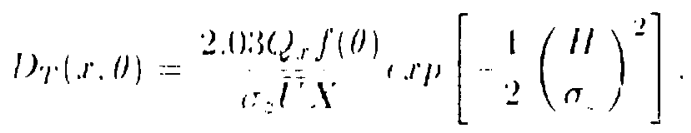

where

$$
\begin{array}{ll}
\mathrm{D}_{\mathrm{T}}(\mathrm{x}, \theta)= & \text { sector averaged integrated concentration } \\
& \left(\mathrm{Ci}-\mathrm{s} / \mathrm{m}^{3}\right) ; \\
\mathrm{Q}_{\mathrm{x}}= & \text { total release remaining at downwind } \\
& \text { distance, } \mathrm{X}(\mathrm{Ci}) ; \\
\mathrm{f}(\theta) \quad & \text { frequency of wind direction towart the sec- } \\
& \text { tor, } \theta ; \\
= & \text { average vertical dispersion coefficient }(\mathrm{m}) ; \\
\sigma_{2} & =\text { average wind spced }(\mathrm{m} / \mathrm{s}) ; \text { and } \\
\mathrm{U} & \text { downwind distance }(\mathrm{m}) .
\end{array}
$$

The coefficients $\sigma_{y}$ and $\sigma_{z}$ were determine. directly from the onsite metcorological data using a me.hod suggested by Draxler (1976). The equations used are:

$$
\begin{aligned}
& \sigma_{!}=\sigma_{0} X f_{1}\left(T / T_{1}\right) \\
& \sigma_{:}=\sigma_{u} \frac{X}{I^{T}} f_{2}\left(T / T_{1}\right)
\end{aligned}
$$

where

$$
\begin{aligned}
& \sigma_{\theta} \quad=\text { standard deviation of the horizontal wind } \\
& =\text { standard deviation of the vertical wind } \\
& \text { speed }(\mathrm{m} / \mathrm{s}) \text {, } \\
& \begin{array}{ll}
X & =\text { downwind distance }(\mathrm{m}), \\
\bar{U} & =\text { average horizontal wind specd }(\mathrm{m} / \mathrm{s}),
\end{array} \\
& f_{1}, f_{2}=\text { funcuions of downwind distance and ther- } \\
& \text { mal stability, } \\
& T=\text { downwind distance in time (s), and } \\
& \mathrm{T}_{\mathrm{i}}=\text { constant dependent on stability and whether } \\
& \text { vertical or horizontal. }
\end{aligned}
$$

The stack release gas at LAMPF is very close to the ambient outside temperature. The stack rise is therefore expecied to be from momentum only. The following stack rise equation for jets presented hy Briggs (1969) uas used: 


$$
\left.\Delta H=1.5 \frac{1}{i}: 1\right)
$$

whero

$$
\begin{array}{ll}
\Delta H & =\text { stack rise }(\mathrm{m}), \\
V_{s} & =\text { stack exit velocity }(\mathrm{m} / \mathrm{s}), \\
\bar{U} & =\text { average wind speed }(\mathrm{m} / \mathrm{s}), \text { and } \\
D & =\text { stack diameter }(\mathrm{m}) .
\end{array}
$$

A value of $9.7 \mathrm{~m} / \mathrm{s}$, based on stack anemometer measurements, was used for $V_{s}$ during 1985 , the same value used during 1984. This velocity gives $\Delta \mathrm{H}$ a range from $17 \mathrm{~m}$ for $1 \mathrm{~m} / \mathrm{s}$ winds to as litue as $1-2 \mathrm{~m}$ for strong winds.

The plume was assumed to remain at effective release height after crossing the canyon. Although the plume is assumed to have the same height above the ground after crossing the canyon, it prohably does sink somewhat as it crosses the canyon. Air containing the emissions is expected to speed up as it travels northward over the "smooth" canyon. Conversely, the air slows down as it approaches ard crosses the mesa on the other side. Also, the air probably rises as it approaches the mesa. Indeed, when southerly and southwesterly winds occur, the wind data show enhanced positive (upward) vertical velocity at East Gatc. Because of the acrodynamic effects, the plume is expected to dip slightly as it moves across the canyon and to rise as it encounters the mesa.

For simplicity, it is also assumed that all available plume gases cross the canyon. Realistically, some of the gases are mixed into the canyon by turbulence. In fact, single channel analyzers have detected annihilation $x$-rays with energy levels equal to those given off by LAMPF in canyons at the Pajarito (TA-18) and Omega (TA-2) sites, Iocaled in Pajarito and Los Alamos Canyons, respectively. This process occurs more during the daytime when turbulent mixing is at a maximum. However, the transport of the radionuclides into the canyon by turbulent exchange is expected to be sinall compared with the amount transported across the canyon.

The LAMPF building is not expected to have a large effect on the transport and dispersion of the emissions. The effective stack height of $35 \mathrm{~m}$ is slightly greater than twice the building height. Therefore, any building wake affecting the plume is expected to be slight. Also, the building with the stack is connected to a long, narrow building housing the proton accelerator beam. This ex- tends $0.4 \mathrm{~km}$ to the west. It is unknown how this building affects the low-level winds.

The L.AMPF metcorological tower's top is $26 \mathrm{~m}$ above ground (stack base). The tower sits on a hill that is $12 \mathrm{~m}$ high. It is unclear how much effect, if any, the hill has on the windflow at wind sensor level. Also, the building with the stack, located just southeast of the tower, probably causes the winds to be lighter at wind sensor level for southeasterly winds. However, southeastcrly winds do not transpor LAMPF relcases toward any of the PICs.

\section{Wind Differences Between the Two Sites.}

a. Directional Shear. Variation of :-ind direction and specd with height is important in determining diffusion of pollutants released from a stack. The wind is slowed down by the frictional effects of the ground. The wind becomes stronger and tums clockwise with increasing height, until, at a certain height (top of the boundary layer), the $w$ ind blows parallel to the isobars and at a speed produced by the pressure gradient force. The top of the boundary layer is usually between 500 to $1000 \mathrm{~m}$. The greatest change of wind direction usually lakes place over the first $100 \mathrm{~m}$ above the ground (surface layer), where much of the speed shear also takes place. Both directional and speed shear of wind can be very dramatic over the lowest $100 \mathrm{~m}$ during the evening. During conditions of light gradient winds and clear skics, radiational cooling of the ground produces a ground-based inversion that promotes vertical stability. Winds near the ground often become "decoupled" from winds above, giving large wind shears. The ASME (1979) suggests a wind shear of $15-30^{\circ}$ between the surface and gradient leveI winds over level terrain. Directional wind shear can be even larger over sloping terrain because of locally produced winds. Radiational cooling over sloping surfaces can cause nighttime drainage winds to flow downslope over the lowest $50 \mathrm{~m}$ or so. Gradient or local winds continuc above $50 \mathrm{~m}$. Winds can turn with height over sloping terrain because of local winds.

The importance of directional wind shcar on the LAMPF plume direction was noticed on several nights in 1985 with limited turbulent mixing. Elevated photon exposures are sometimes seen at the NE PIC, while the $12 \mathrm{~m}$ ancmometer at East Gate indicates south-southwesterly $\left(202^{\circ}\right)$ winds. However, the anemometer at the $26 . \mathrm{m}$ level at LAMPF indicates the winds are $15.20^{\circ}$ 
clockwise of the East Gate winds, or directed more toward the NE PIC. The elevated levels at the NE PIC site during these times suggest that emissions at the $35 \mathrm{~m}$ level are being carried by southwesterly winds. Winds indicated by the higher LAMPF anemometer correlate better with the direction of the highest photon levels than do the winds given by the East Gate anemometer during these times.

We believe that the difference in winds between the two sites during some nights results more from height difference than from site difference. Many other nights show that the wind direcuons are much more similar between the two sites. This underlines the variable charactcristics of wind shear from night to night, if not from hour to hour. Also, based on the PIC measurements, the wind shear takes place near the effective stack release icvel $(35 \mathrm{~m})$ but not at the 12 or $26 \mathrm{~m} \mathrm{level}$ on some nights.

Because there is uncertainty in estimating vertical wind shear by comparing two sites, wind direction shear was looked at by comparing winds at different levels at the 92-m, TA-50 tower located $4 \mathrm{~km}$ west-southwest of the LAMPF stack. A consistent wind shear is observed on many nights; a low-level westerly wind occurs at the $11-$ and $22-\mathrm{m}$ levels, while a southwesterly wind is observed at the 46 - and $92-\mathrm{m}$ levels. Wind shear is a result of a low-level drainage wind along the sloping plateau and a higher-level wind resilting from channeled flow by the Rio Grande Valley. Because East Gate is at a lower elevation (closer to the Rio Grande Valley) and it has a more gentle slope immediately to the west, drainage winds do not occur as often as at TA-50. However, nighttime winds probably also tend to be more southwesterly at East Gate and LAMPF with increasing height.

It was not possible to incorporate dircctional wind shear into the modeling in this study. Changing wind direction up to stack level is sometimes important at night. However, modeling errors are expected to be modest when averaged over large time periods.

Other effects from wind shear were not taken into account for simplicity. First, the directional shear was not considered to estimate the plume radionuclide concentrations. In fact, vertical directional wind shear has the effect of spreading out the relcase in the horizontal (higher $\left.\sigma_{y}\right)$ and thereby causing lower concentrations in the plume. The variations of wind direction $\left(\sigma_{\theta}\right)$ and vertical velocity $\left(\sigma_{w}\right)$ also change with height, thereby changing the horizontal $\left(\sigma_{y}\right)$ and vertical $\left(\sigma_{\ell}\right)$ spread of the plume. The horizontal wind turbulence generally decreases with height; this would tend to make the centerline concentration higher downwind, and less of the radionuclides would spread laterally. Vertical turbulence tends to increase with increasing height near the ground; therefore, vertical winds taken at a higher level would tend to spread more of the radionuclides down to the ground than winds at a lower level. However, winds during the 86-day study period indicate that average values of $\sigma_{\theta}$ and $\sigma_{\phi}$ were quite similar between the two tower sites. So the expected dominant effect is an increase in $\sigma_{y}$ because of wind direction changes with height.

We believe that the model accuracy results suffer when the 12-m height rather than the effective stack height is used. The accuracy of the transport direction is best when estimated stack level wind direction is used.

b. Speed Differences. The sometimes large wind speed differences between the two sites were not taken into account in this study for simplicity. Much of the wind speed variation is attributed to the effect of the Los Alamos Canyon. Air spceds up while passing over the Canyon because the Canyon is aerodynamically smooth compared to the adjacent mesas. East Gate average windspecds and ratios of East Gate/LAMPF winds are plotted in Fig. 11 for different wind directions. Note that the strongest winds are centered over the southwesterly direction, indicating the persistent channeled winds flowing up the Rio Grande. Winds are considerably higher at East Gate than at LAMPF for the directions east-southeast through southwest. These are all winds that bring air across the Los Alamos Canyon to East Gate.

3. Model Sensitivity. The effects of changes in different variables on predicted concentrations are shown in Table IV. The infinite model is most sensitive to changes in distance from plume centerline ( $Y$ ) or wind direction. The effect of increasing the distance from the plume centerline is the greatest during stable periods ( $\sigma_{\mathrm{y}}$ is smaller). A change in $Y$ from 0 to $100 \mathrm{~m}$ can cause a decrease in $\chi$ of $69 \%$. At a downwind distance of $800 \mathrm{~m}$, a difference of $100 \mathrm{~m}$ in $\mathrm{Y}$ is equal to a change of wind direction of only $6^{\circ}$. Therefore, the model is extremely sensitive to wind direction. Windspeed can also affect concentrations. A threefold increase in windspeed gives close to a $50 \%$ reduction in $X$. Therefore, based on measurement uncertainty (Table III) of wind direction and speed, $X$ can he largely affected by wind direction measurement uncertaintics, but less by windspeed. The effects of changes of other variables can be seen to be smaller. 

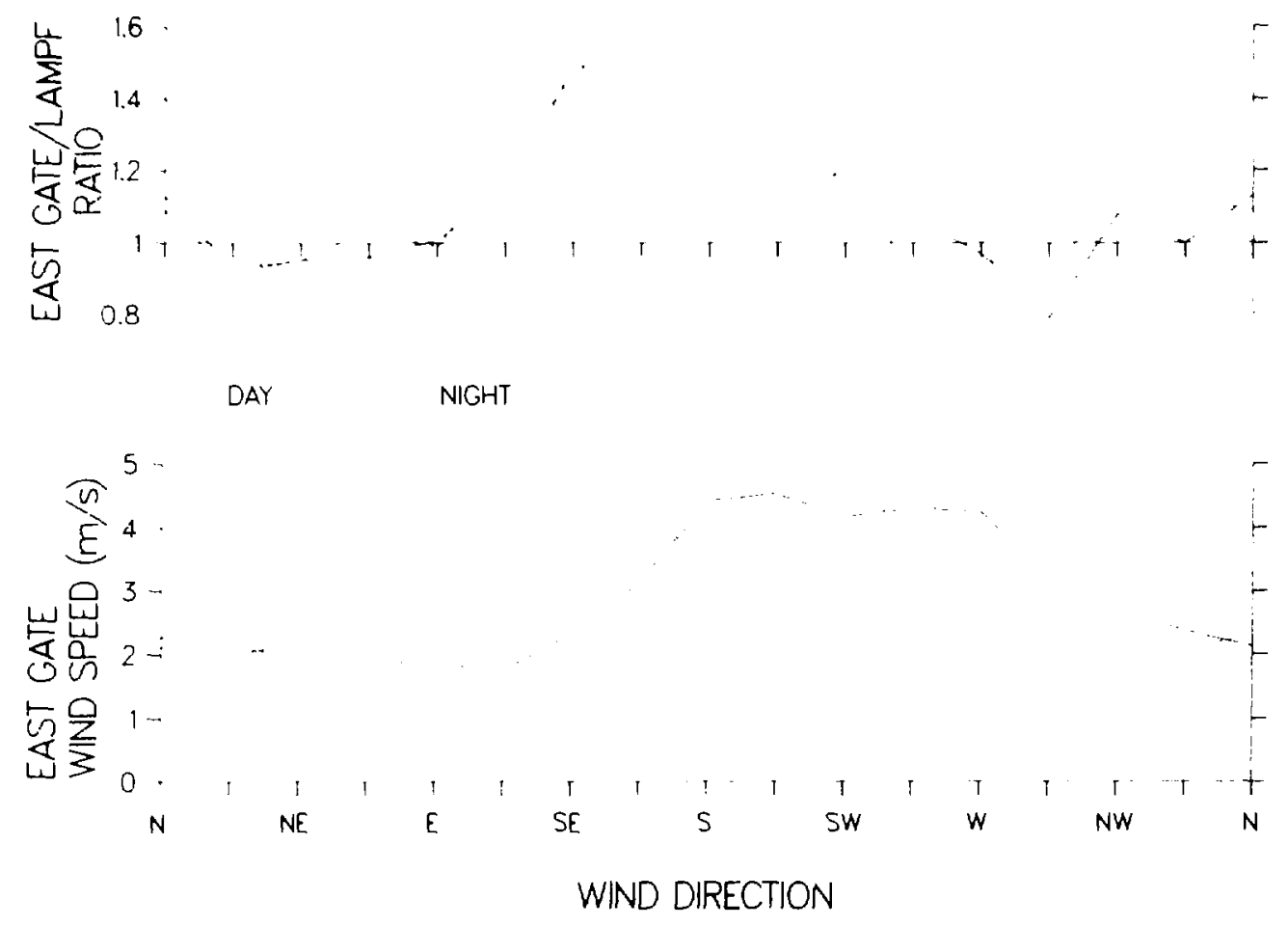

Fig. 11. East Gate LAMPF windspeed ratio and East Gate windspeeds by direction during an 86-day study period.

\section{Modeling Results - Short Term}

Daily model predictions, based on integration of 15 minute predictions, were made and compared with measured values during 1985. Comparison of predicted and measured values for the three siles is shown in Fig. 12, and the related statistics are shown in Table $V$. There is good correlation between predicted and measured data. Correlation is strongest at the north-northeast site and not as strong at the other two sites. However, the correlation is still high at these sites, with $\mathrm{R}=0.78$ and 0.72 and corresponding $R^{2}$ values of 0.62 and 0.52 . This implies over half of the measured values variation is explained by the model at these sites, with an even higher $\mathrm{R}^{2}$ of 0.81 at the north-northeast site. The regression line slopes are close to 1 at the north and north-northeast sites, indicaling a close correspondence of predicted and measured values.

The finite model was also used to predict daily LAMPF plume photon radiation. This model's predictions are less than predictions given by the infinite case and most measurcd values (Table VI). The ratio of finite/ infinite daily predictions ranged from 0.72 for the north site to 0.79 for the north-northeast and 0.84 for the northeast site. For all sites, the correlation coefficients using the finite model were nearly identical to those using the infinite model. The ratios of finite/infinite are closer to 1 at the north-northeast and northeast sites.

The infinite model clearly is a more conservative radiation level indicator. The infinite model is preferred because its predictions are closer to measured values than those of the finite model. It is also important that the infinite model is much simple: and less expensive to run than the more complicated finite model. For the remainder of this report, "model" is understood to mean "infinite model" unless otherwise stated. Furhermore, shon term and scasonal models are both based upon the infinite model.

Daily model predictions were also made using the LAMPF wind data (Fig. 13 and Table VII). Correlation is good between measured and predicted values at the north and north-northcast sites, with correlations of 0.81 and 0.76 , respectively. However, the model overpredicts the 
Table IV. Sensitivity of Air Concentration $(X)$ from Variable Changes

\begin{tabular}{|c|c|c|c|c|c|c|}
\hline & $0_{x}^{\prime}(\mathrm{Ci} / \mathrm{s})$ & $r(m) *$ & $H(m)$ & $\bar{u}(\mathrm{~m} / \mathrm{s})$ & $\sigma Y(m)^{\star \star}$ & $\sigma_{2}$ \\
\hline Variable Changes & $\pm 10 \%$ & $\begin{array}{l}\text { to } 50 \text { from } D \\
\text { (to } 100 \text { from } 0 \text { ) }\end{array}$ & $\begin{array}{l}+5 \\
(+10)\end{array}$ & $\begin{array}{l}\text { to } 3 \text { from } 1 \\
\text { (to } 10 \text { from } 3 \text { ) }\end{array}$ & $\begin{array}{l}+10 \% \text { at } Y=50 \mathrm{~m} \\
(+10 \% \text { at } Y=100 \mathrm{~m})\end{array}$ & $\begin{array}{l}+10 \% \text { at } \\
(+10 \% \text { at }\end{array}$ \\
\hline \multicolumn{7}{|l|}{ Stability } \\
\hline Unstable $\left(\sigma_{y}=110 \mathrm{~m} ; \sigma_{z}=70 \mathrm{~m}\right)$ & $-10 \%$ & $\begin{array}{l}-10 \% \\
(-34 x)\end{array}$ & $\begin{array}{l}-3.5 \% \\
(-8.0 \%)\end{array}$ & $\begin{array}{r}-42 \% \\
\cdots\end{array}$ & $\begin{array}{l}-6.5 \% \\
(-2.0 x)\end{array}$ & $\begin{array}{l}-7.6 \% \\
(-5.8 \%)\end{array}$ \\
\hline Neutral $\left(\sigma_{y}=85 \mathrm{~m}_{;} \sigma_{z}=50 \mathrm{~m}\right)$ & $\pm 10 \%$ & $\begin{array}{l}-16 \% \\
(-50 \%)\end{array}$ & $\begin{array}{l}-6.5 \% \\
(-14 \%)\end{array}$ & $\begin{array}{c}\cdots \\
(-58 \%)\end{array}$ & $\begin{array}{l}-6.0 x \\
(-1.5 x)\end{array}$ & $\begin{array}{l}-6.2 \% \\
(-2.5 \%)\end{array}$ \\
\hline stable $\left(\sigma_{y}=65 \mathrm{~m} ; \sigma_{z}=35 \mathrm{~m}\right)$ & $\pm 10 \%$ & $\begin{array}{l}-26 x \\
(-69 \%)\end{array}$ & $\begin{array}{l}-15 \% \\
(-28 z)\end{array}$ & $-42 \%$ & $\begin{array}{l}-2.5 x \\
(+11 x)\end{array}$ & $\begin{array}{l}-3.1 \% \\
(+4.9 \%)\end{array}$ \\
\hline
\end{tabular}

*50 $\mathrm{m}=3^{\circ}$ wind direction at $800 \mathrm{~m}$ downwind.

**Plus $10 \%$ change in $\sigma_{y}$ at $y=0$ yields $-10 \%$ in $X$.

***Plus $10 \%$ chanage in $\sigma_{z}$ at $z=H$ yields $-10 \%$ in X. 


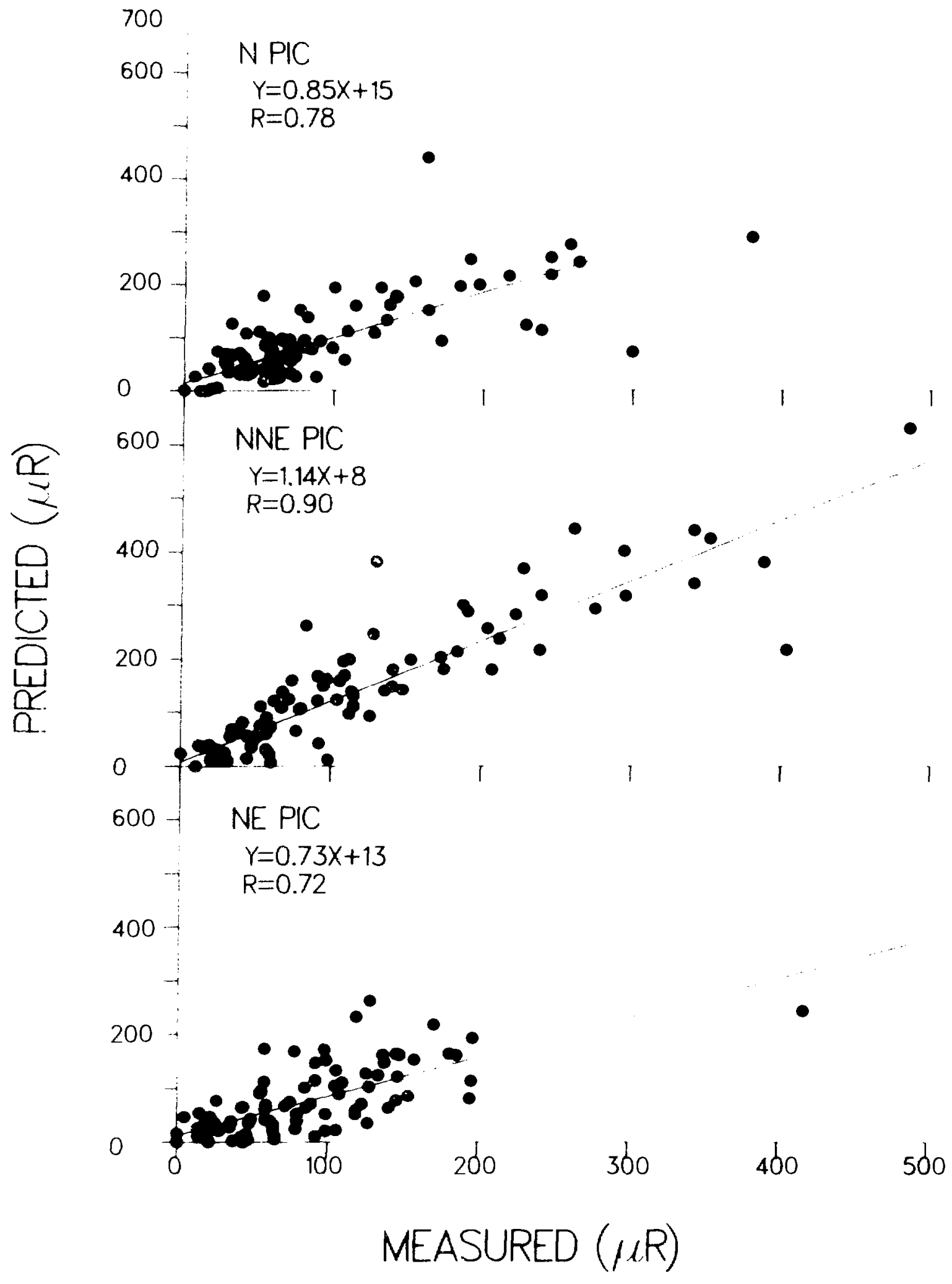

Fig. 12. Predicted versus measured daily external radiation from LAMPF emissions at sites norlh, north-northeast. and northeast of LAMPF on State Road 4 using East Gate winds. 
Table V. Regression Analysis Statistics for Predicted Versus Measured Daily

External Radiation at Three Sites from LAMPF Emissions During 1985

(predictions are based on East Gate winds, Fig. 12)

\begin{tabular}{|c|c|c|c|c|c|c|c|c|}
\hline PIC & Slope & $\begin{array}{c}Y- \\
\text { Intercept }\end{array}$ & $\mathbf{R}^{*}$ & $\mathbf{R}^{2}$ & $P^{* *}$ & $\begin{array}{l}\text { Measured } \\
(\mathrm{X})\end{array}$ & $\begin{array}{l}\text { Predicted } \\
\text { (Y) }\end{array}$ & $\begin{array}{l}\text { Number } \\
\text { of Days }\end{array}$ \\
\hline $\mathbf{N}$ & 0.85 & 15 & 0.78 & 0.62 & $99.9 \%$ & 74 & 78 & 123 \\
\hline NNE & 1.14 & 8 & 0.90 & 0.81 & $99.9 \%$ & 100 & 122 & 110 \\
\hline$N E$ & 0.72 & 13 & 0.72 & 0.52 & $99.9 \%$ & 77 & 70 & 101 \\
\hline
\end{tabular}

* Corrclation coefficient.

**Probability correlation did not happen by chance.

Table VI. Comparison of Infinite and Finite Model Results with Measured Daily External Radiation at Three Sites from LAMPF Emissions During 1985 (predictions are based on Fast Gate winds)

\begin{tabular}{|c|c|c|c|c|c|}
\hline \multirow[b]{2}{*}{ PIC } & \multirow{2}{*}{$\begin{array}{l}\text { Number } \\
\text { of Days }\end{array}$} & \multirow{2}{*}{$\begin{array}{l}\text { Measured } \\
\qquad(\mu R)\end{array}$} & \multicolumn{2}{|c|}{ Predicted } & \multirow{2}{*}{$\begin{array}{l}\text { Finite } \\
\text { Infinite }\end{array}$} \\
\hline & & & Finite & Infinite & \\
\hline$N$ & 123 & 74 & 56 & 78 & 0.72 \\
\hline NNE & 110 & 100 & 96 & 122 & 0.79 \\
\hline NE & 101 & 77 & 59 & 70 & 0.84 \\
\hline
\end{tabular}

north sector by $78 \%$. The model underpredicts the northeast sector, besides having a lower correlation coefficient of 0.65. Apparently the plume travels more frequently toward the noriheast than the LAMPF wind data indicates.

The pattern of corrclation using the LAMPF winds during 1985 is very similar to the one during 1984: the model considerably overpredicts in the north sector and underpredicts in the northeast sector. The measured versus predicted correlation coefficient drops off for the northeast site. The correlation using East Gate winds is better than the correlation using LAMPF winds during both years, especially in the northeast sector. It appears that the winds measured at LAMPF cannot represent the plume spread over the three directions as well as the East Gate winds can.

It is likcly that the data measured by the LAMPF U.V wind system, with angle of attack corrections applied to the 15-minute averages, are not as representative as the
East Gate propeller anemometer system installed during 1985. It has bcen observed at both OHIL and East Gate that the winds tended to be concentrated or "spiked" in one direction as measured by the U-V system, while the propeller vane system showed the winds to be more evenly distributed around that specific direction.

\section{Accuracy of Model vs Meteorological Variables}

Further analyses were made to check the model's accuracy versus wind speed, standard deviation of wind direction $\left(\sigma_{\theta}\right)$, and standard deviation of vertical wind direction $\left(\sigma_{\phi}\right)$ at each of the three sitcs. These analyses were made for both daytime and nighttime and were limited to an 86-day period, which contains data for all three sites. Predicted and measured values were calculated and added up under cach category of wind speed, $\sigma_{\theta}$ and $\sigma_{\phi}$.

Ratios of predicted versus measured radiation exposures for different windspeeds are shown in Table VIlI. 


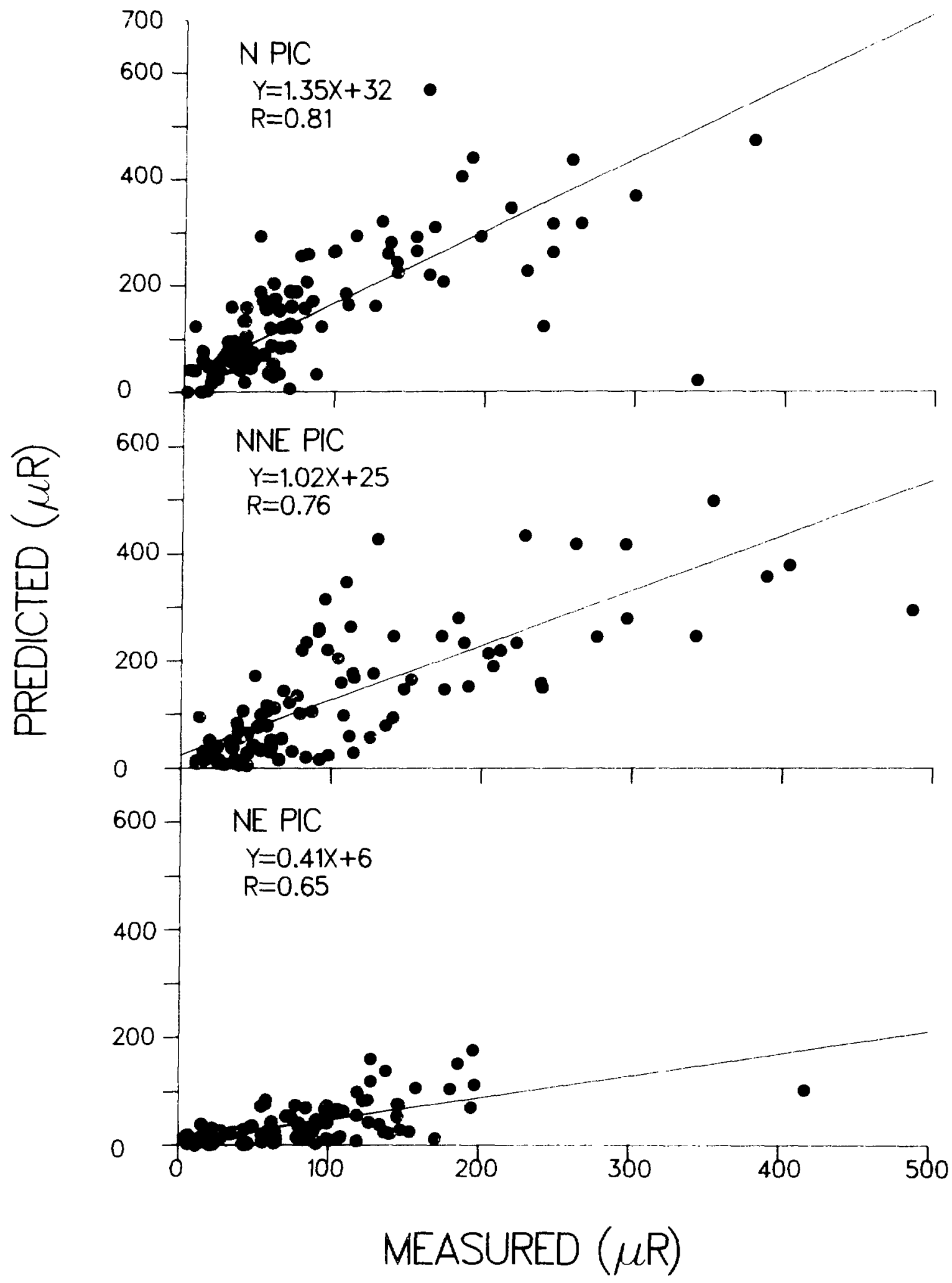

Fig. 13. Predicted versus measured daily external radiation from LAMPF emissions at sites north, north-northeast, and northeast of LAMPF on State Road 4 using LAMPF winds. 
Table VII. Regression Analysis Statistics for Predicted Versus Measured Daily

External Radiation at Three Sites from LAMPF Emissions During 1985

(predictions are based on LAMPF winds, Fig. 13)

\begin{tabular}{|c|c|c|c|c|c|c|c|c|}
\hline PIC & Slope & $\begin{array}{c}Y- \\
\text { Intercept }\end{array}$ & $\mathbf{R}^{*}$ & $\mathbf{R}^{2}$ & $\mathbf{p * *}$ & $\begin{array}{l}\text { Measured } \\
\text { (X) }\end{array}$ & $\begin{array}{l}\text { Predicled } \\
\text { (Y) }\end{array}$ & $\begin{array}{l}\text { Number } \\
\text { of Days }\end{array}$ \\
\hline & 1.3 & 32 & 0.81 & 0.66 & $99.9 \%$ & 74 & 132 & 123 \\
\hline NNE & 1.02 & 25 & 0.76 & 0.58 & $99.9 \%$ & 100 & 127 & 109 \\
\hline NE & 0.41 & 6 & 0.65 & 0.43 & $99.9 \%$ & 77 & 37 & 102 \\
\hline
\end{tabular}

* Correlation cocflicicnt.

**Probabilicy correlacion did not happen by chance.

Table VIIl. Predicted Versus Measured External Radiation Ratios

at Three Sites for Different Windspeeds

(over entire 86-day study - East Gate Winds)

\begin{tabular}{|c|c|c|c|c|c|c|c|c|c|}
\hline \multirow[b]{2}{*}{$\begin{array}{l}\text { Windspeed } \\
(\mathrm{m} / \mathrm{s}) \\
\end{array}$} & \multicolumn{3}{|c|}{ Day } & \multicolumn{3}{|c|}{ Night } & \multicolumn{3}{|c|}{ Total } \\
\hline & $\begin{array}{c}\text { N } \\
\text { PIC }\end{array}$ & $\begin{array}{l}\text { NNE } \\
\text { PIC }\end{array}$ & $\begin{array}{l}\text { NE } \\
\text { PIC }\end{array}$ & $\stackrel{N}{\text { PIC }}$ & $\begin{array}{l}\text { NNE } \\
\text { PIC }\end{array}$ & $\begin{array}{l}\text { NE } \\
\text { PIC }\end{array}$ & $\begin{array}{c}\mathrm{N} \\
\mathrm{PIC}\end{array}$ & $\begin{array}{l}\text { NNE } \\
\text { PIC }\end{array}$ & $\begin{array}{l}\text { NE } \\
\text { PIC }\end{array}$ \\
\hline $0-2.5$ & 2.06 & 1.83 & 1.37 & 0.45 & 0.38 & 0.42 & 1.04 & 0.75 & 0.60 \\
\hline $2.5-5.0$ & 1.77 & 1.86 & 1.33 & 1.27 & 1.56 & 0.97 & 1.54 & 1.68 & 1.05 \\
\hline $5.0-7.5$ & 1.20 & 1.24 & 1.12 & 1.66 & 2.12 & 1.22 & 1.30 & 1.59 & 1.19 \\
\hline$>7.5$ & $\underline{0.82}$ & $\underline{0.91}$ & 1.27 & $\underline{0.93}$ & 2.00 & $\underline{1.25}$ & $\underline{0.85}$ & 1.43 & 1.25 \\
\hline Total & 1.64 & 1.60 & 1.27 & 0.95 & 1.30 & 0.90 & 1.32 & 1.42 & 0.99 \\
\hline
\end{tabular}

The model is seen to overpredict at all sites with light, daytime winds. These are times when the atmosphere is the most unstable (most diffusive). It is possible some of the radionuclides are being mixed down into the canyon during these periods - the model does not account for this. Or, the dispersion parameters, $\sigma_{y}$ and $\sigma_{z}$ may be underestimating the true atmospheric diffusive power at these times. The predicted values are closer to or even less than measured values for stronger daytime winds or more neutral conditions. Predicted and measured values show good agreement for the night as a whole. However, predicted values are less than measured values at all sites at night for light winds, while predicted values generally exceed measured values at night for stronger winds. In general, the model tends to overpredict during unstable cases and underpredict during stable cases.
A similar analysis, but for different $\sigma_{\theta}$ 's, is shown in Table IX. The model again appears to overpredict during unstable daytime conditions (larger values of $\sigma_{\theta}$ ). The model also underpredicts during stable, nighttime hours (smaller values of $\sigma_{\theta}$ ), especially in the north. The values of $\sigma_{\theta}$ are probably not representing the true lateral diffusive capabilitics of the atmosphere during the most unstable cases.

Another analysis based on $\sigma_{\phi}$ 's is shown in Table X. Results are similar to those analyses for different windspeeds and $\sigma_{\theta}$ 's, namely, that the model generally overpredicts for very unstable cases (large $\sigma_{0}$ ) during the daytime and underpredicts for very stable conditions (small $\sigma_{0}$ ) during the night. However, the model clearly underpredicts for small $\sigma_{\phi}$ 's and tends to overpredict for large $\sigma_{0}{ }^{\prime} s$ at night. It appears that the accuracy of the model is 
Table IX. Predicted Versus Measured External Radiation Ralios at Three Sites for Different Horizontal Wind Direction Standard Deviations ( $\sigma_{\theta}$ )

(over entire 86-day study - East Gate Winds)

\begin{tabular}{|c|c|c|c|c|c|c|c|c|c|}
\hline \multirow[b]{2}{*}{ (degrees) } & \multicolumn{3}{|c|}{ Day } & \multicolumn{3}{|c|}{ Night } & \multicolumn{3}{|c|}{ Total } \\
\hline & $\begin{array}{c}\mathrm{N} \\
\text { PIC }\end{array}$ & $\begin{array}{l}\text { NNE } \\
\text { PIC }\end{array}$ & $\begin{array}{l}\text { NE } \\
\text { PIC }\end{array}$ & $\begin{array}{c}\mathrm{N} \\
\text { PIC }\end{array}$ & $\begin{array}{l}\text { NNE } \\
\text { PIC }\end{array}$ & $\begin{array}{l}\text { NE } \\
\text { PIC }\end{array}$ & $\stackrel{\mathrm{N}}{\mathrm{PIC}}$ & $\begin{array}{l}\text { NNE } \\
\text { PIC }\end{array}$ & $\begin{array}{l}\text { NE } \\
\text { PIC }\end{array}$ \\
\hline$<7.5$ & $\ldots$ & $\cdots$ & $\ldots$ & 0.14 & 1.05 & 1.01 & 0.24 & 0.98 & 1.01 \\
\hline $7.5-12.5$ & 0.99 & 1.49 & 0.89 & 0.86 & 1.52 & 0.89 & 0.90 & 1.51 & 0.89 \\
\hline $12.5-17.5$ & 1.42 & 1.41 & 0.82 & 1.22 & 1.31 & 0.93 & 1.33 & 1.36 & 0.89 \\
\hline 17.5 & 1.96 & 1.92 & 2.62 & 0.89 & $\underline{0.80}$ & 0.81 & 1.63 & 1.48 & 1.49 \\
\hline Total & 1.64 & 1.60 & 1.27 & 0.95 & 1.30 & 0.90 & 1.32 & 1.42 & 0.99 \\
\hline
\end{tabular}

Table X. Predicted Versus Measured External Radiation Ratios at Three Sites for Different Vertical Wind Direction Standard Deviations $\left(\sigma_{\phi}\right)$ (over entire 86-da; period - East Gate Winds)

\begin{tabular}{|c|c|c|c|c|c|c|c|c|c|}
\hline \multirow[b]{2}{*}{ (degrees) } & \multicolumn{3}{|c|}{ Day } & \multicolumn{3}{|c|}{ Night } & \multicolumn{3}{|c|}{ Tolal } \\
\hline & $\begin{array}{c}\mathbf{N} \\
\text { PIC }\end{array}$ & $\begin{array}{l}\text { NNE } \\
\text { PIC }\end{array}$ & $\begin{array}{l}\text { NE } \\
\text { PIC }\end{array}$ & $\begin{array}{c}\text { N } \\
\text { PIC }\end{array}$ & $\begin{array}{l}\text { NNE } \\
\text { PIC }\end{array}$ & $\begin{array}{l}\text { NE } \\
\text { PIC }\end{array}$ & $\stackrel{N}{\text { PIC }}$ & $\begin{array}{l}\text { NNE } \\
\text { PIC }\end{array}$ & $\begin{array}{l}\text { NE } \\
\text { PIC: }\end{array}$ \\
\hline$<5$ & 1.10 & 1.45 & 1.02 & 0.31 & 0.92 & 0.82 & 0.46 & 1.00 & 0.85 \\
\hline $5-7.8$ & 1.50 & 1.44 & 1.06 & 1.28 & 1.55 & 0.94 & 1.39 & 1.50 & 0.98 \\
\hline $7.8-10$ & 1.50 & 1.51 & 1.45 & 1.31 & 1.36 & 1.31 & 1.45 & 1.45 & 1.38 \\
\hline$>10$ & $\underline{2.35}$ & $\underline{2.50}$ & 3.21 & 1.10 & 1.79 & $\underline{1.15}$ & $\underline{2.09}$ & $\underline{2.30}$ & $\underline{2.17}$ \\
\hline Total & 1.64 & 1.60 & 1.27 & 0.95 & 1.30 & 0.90 & 1.32 & 1.42 & 0.99 \\
\hline
\end{tabular}

more dependent on values of $\sigma_{\phi}$ than of $\sigma_{\theta}$. One possible reason is that with large vertical turbulence or $\sigma_{\phi}$, more of the gases are mixed down into the canyon, thereby causing an overprediction. Also, larger vertical turbulence $\left(\sigma_{\phi}\right)$ does not necessarily reflect a similar increase of horizontal turbulence $\left(\sigma_{\theta}\right)$. Another possible cause is that the method used to calculate $\sigma_{\phi}$ is not representing the actual vertical dispersion accurately. Also note that the model overpredicts for large $\sigma_{\phi}$ 's. However, only a small amount of hours during the night have $\sigma_{\phi}>7.8^{\circ}$.

Average predicted and measured values were also compared hourly for the 86-day period (Fig. 14). The data clearly indicate that the model systematically overpredicts at all sites during the daytime. One possible reason is that some of the radionuclides may be mixing down into the canyon, while the model assumes no mixing. Another possibility is that the afternoon turbulence is understated by the method used to calculate $\sigma_{\mathrm{y}}$ and $\sigma_{\mathrm{z}}$.
The nighttime exposure, especially after midnight, is underpredicted at the north site, while the model closely predicts the nighttime measured values in the northnortheast and northeast.

\section{E. Modeling Results - Seasonal}

The seasonal model was used to estimate exposures at the threc sites for the 86-day period with complete data. These estimates are compared with the estimates derived from adding up the separate $24-\mathrm{h}$ estimates and with the measured data (see Table XI). The sums of the $24 \mathrm{~h}$ predictions closely match the measurcd values, except at the north-northeast PIC, where the model overpredicts by $25 \%$. The seasonal model, which uses an average windspecd and $\sigma_{i}$ for the entire period, gives somewhat higher cstimates, and overpredicts at all sites. 


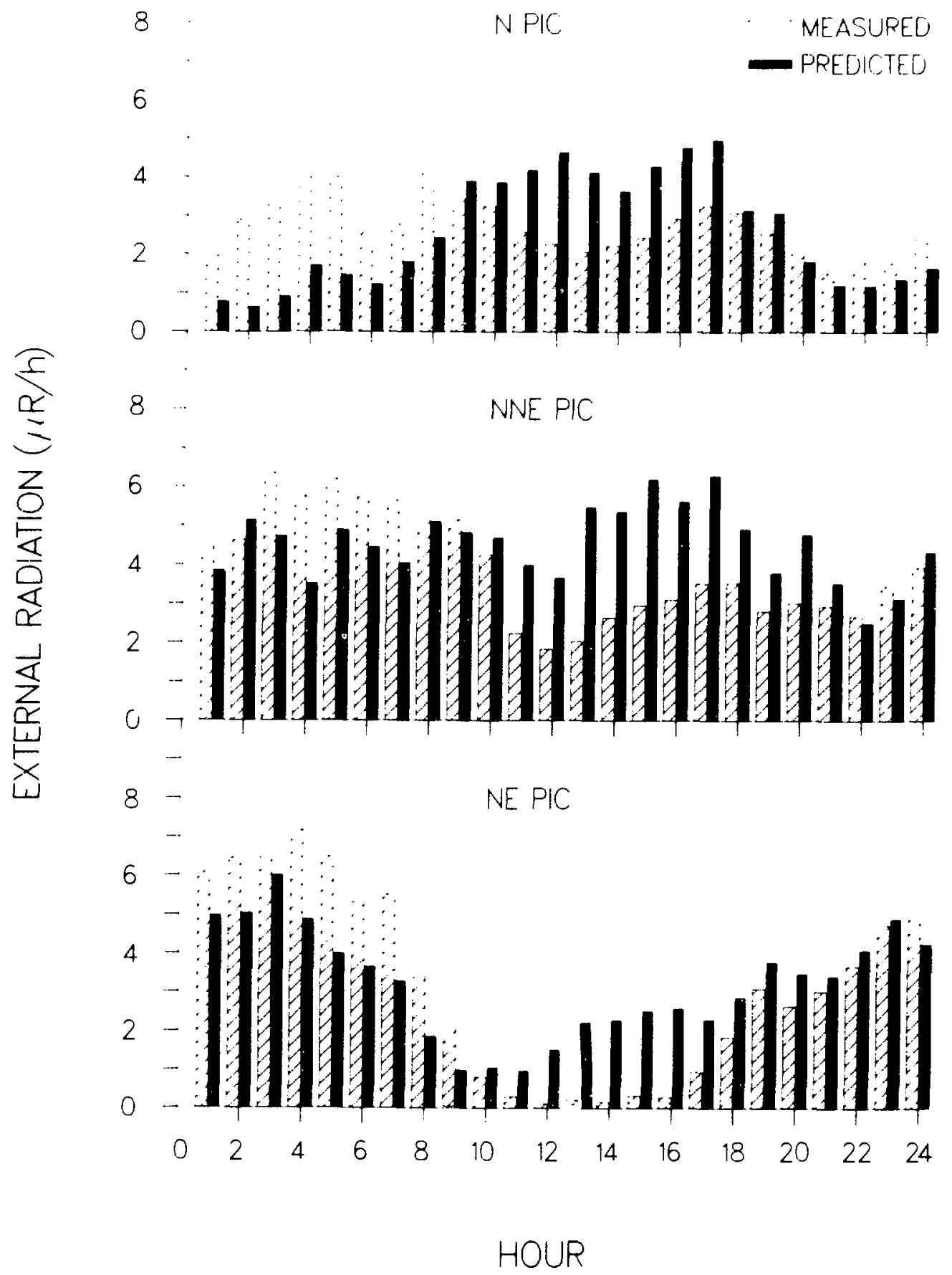

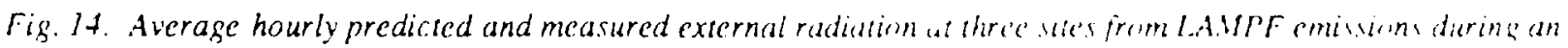
86-day study period. 
Table XI. Comparison of PIC-Measured External Radiation levels

With Predicted Levels ( $m R$ ) from LAMPF Emissions

Using East Gate Winds for 86 Days During 1985

\begin{tabular}{|c|c|c|c|}
\hline PIC Site & Measured & Slıort-Term Model & Seasonal Model \\
\hline$M$ & 5.6 & 5.9 & 8.1 \\
\hline NNE & 8.0 & 10.0 & 11.3 \\
\hline NE & $\underline{7.0}$ & 6.9 & 9.6 \\
\hline$N$ through NE & 6.9 & 7.6 & 9.7 \\
\hline
\end{tabular}

The seasonal model was also broken down into pe. riods of day and night. The results (Table XII) show that when the model is calculated using separate $\sigma_{2}$ and windspeeds for day and night, predictions are less conscrvative and closer to measured values. The estimates are also closer to values derived from the sum of $24 \mathrm{~h}$ estimates. The separate cyaluation of day and night levels is a slight improvement over using a single calculation when using the scasonal model. One reason may be that daytime calculations fully reflect the rather large $\sigma_{z}$ values, while the combined day and night values do not.

The seasonal model, using combined day and night conditions, and the short-term model were also used to calculate radiation levels using winds measured at LAMPF. These estimates are compared with measured values in Table XIII. The seasonal model overpredicts in all sectors, especially in the north-northeast. The seasonal model also gives higher estimates than those given by the short-term model, except in the north sector. The LAMPF winds give generally less accurate estimates for specific sectors than the East Gate winds using both the short-term and seasonal models. There are more extremes (over and underprediction) using the LA.MPF winds.
The results also show that there is poor correlation between the short-term and scasonal models using LAMPF winds. It is likely that the measured LAMPF winds are not as uniformly distributed across the sectors as the East Gate winds are.

The seasonal model was also used to predict annual external radiation on State Road 4 during 1985 from LAMPF emissions. Predicted values using East Gate winds ranged from a maximum of $21 \mathrm{mR}$ to the northnortheast, $18 \mathrm{mR}$ to the northeast, $16 \mathrm{mR}$ to the north, and to 11 and $6 \mathrm{mR}$ to the north-northwest and northwest of LAMPF, respectively. The combined predicted value of nearly $14 \mathrm{mR}$ is slightly higher than the $11.4 \mathrm{mrem}$ measured by the TLD network.

\section{SUMMARY AND CONCLUSIONS}

A network of monitors on State Road 4 continued to measure external radiation levels from LAMPF emissions. The exposure levels along with onsite meteorological data were analyzed to determine spatial and temporal patterns. The meteorological data along with LAMPF release data were also used to predict photon exposures and were compared with measured values.

Table XII. Comparison of Seasonal Model Predicted External Radiation (mR) Using Combined Day and Night and Separate Day and Night Periods for 86 Days During 1985

\begin{tabular}{|c|c|c|c|c|}
\hline PIC Site & Combined & $\begin{array}{c}\text { Separate } \\
(D a y+N i g h t)\end{array}$ & Day & Night \\
\hline$N$ & 8.1 & 7.6 & 3.2 & 4.4 \\
\hline NNE & 11.3 & 10.6 & 3.4 & 7.2 \\
\hline NE & 9.6 & 8.9 & $\underline{2.8}$ & $\underline{7.0}$ \\
\hline$N$ through NE & 9.7 & 9.0 & 2.8 & 6.2 \\
\hline
\end{tabular}




\section{Table XIII. Comparison of PIC-Measured External Radiation Levels With Predicted Lecels (mR) from LAMPF Emissions U/sing L. AMPF Winds for 86 Days During 1985}

\begin{tabular}{|c|c|c|c|}
\hline PIC Site & Measured & Short-Term Model & Seasonal Model \\
\hline$N$ & 5.6 & 9.9 & 8.3 \\
\hline NNE & 8.0 & 10.1 & 14.7 \\
\hline NE & $\underline{7.0}$ & 3.4 & 8.9 \\
\hline$N$ through $N E$ & 6.9 & 7.8 & 10.6 \\
\hline
\end{tabular}

In summary, the infinite cloud approximation was found to be an excellent indication of daily exposures at 700-900 $\mathrm{m}$ downwind of the LAMPF stack, using East Gate winds. The more complex finite cloud model consistently yielded lower daily estimates. Based on its simplicity, the infinite cloud method is recommended over the finite method at $700 \mathrm{~m}$ downwind or greater. Although the infinite model gives good overall results, it docs systematically overpredict during the day or in unstable conditions. The seasonal form of the infinite model generally overpredicts exposures over longer time periods (months). The seasonal model gives better results when average cay and nighe statistics are calculated separately. Although the seasonal model is quite accurate and convenient to use, the addition of $24 \mathrm{~h}$ estimates based on the short-term infinite model gives considerably more accurate estimates of long-term, measured external radiation.

The primary conclusions of this study are the following:

1) A persistent, locally produced up-valley wind is responsible for causing the maximum exposures to $\propto C$ cur to the northeast and north-northeast of LAMPF, while a southerly upslope wind also helps to give higher exposures to the north.

2) The channeling of large-scale winds, especially at night, is most likely responsible for the high frequency of up-valley winds, while the upslope flow is forced by daytime solar heating.

3) An $80 \%$ reduction in the 1985 LAMPF emissions from 1984 resulted in a reduction of exposures by nearly as much.
4) External radiation is much greater to the northeast of LAMPF, somewhat greater to the norh-northeast, and slightly less to the north during the night than during the day, largely because of persistent southsouthwesterly and southwesterly $r$ inds.

5) Gencrally, external radiation is considerably higher during the night due to decreased atmospheric dispersion.

6) Predicted daily exposures using the simple infinite cloud approximation corrclate very well with measured exposures. The more complex finite cloud model estimates are over $20 \%$ less than those of the infinite model.

7) Differences in wind, erpecially direction, causes unccrtainty in model predictions for specific directions. There are additional uncerainties in using winds lower than the stack height because shear can be significant over the lowest $50 \mathrm{~m}$ above the ground.

8) Extcrnal radiation estimates using LAMPF winds continue to be less accurate than those using East Gate winds.

9) Windspeeds at East Gate are higher than those at LAMPF for southeast through southwest winds.

10) Predicted exposure values consistently exceed measurcd values during the daytime. This may be from radionuclide mixing into the Canyon not accounted for by the model, the underestimation of diffusion 
caused by calculated values of $\sigma_{y}$ and $\sigma_{L,}$ or because the concentration distributions are not Gaussian.

11) The seasonal model yields rather accurate exposure estimates, which are generally higher than measured values and estimates derived from adding up $24-\mathrm{h}$ predictions. The seasonal model is seen as a useful tool in determining accurate long-term exposure estimates.

12) The scasonal model gives somewhat lower external radiation estimates that are closer to measured values when average day and night conditions are calculated separatcly.

13) Based on these modeling results and those in 1984, a Gaussian model is expected to accurately (within a factor of 2) predict daily radioactive or nonradioactive levels up to $1 \mathrm{~km}$ or so downwind (on mesa top) if onsite metenrological and source data are available. The accuracy of the model for specific locations is less for smaller averaging periods (I $5 \mathrm{~min}$ utes to several hours) and greater for larger averaging periods (several days to months). The difficult part of the modcling is generally not estimating the concentrations, but the precise direction of travel. Further model validation using additional PIC sites or using some form of uracer would increase confidence in the models.

\section{NEW DEVELOPMENTS AND FURTHER STUDY}

The three PICs will continue to monitor radiation levels in the future. A propeller anemometer system was recently installed at the LAMPF meteorological tower. This wind system is identical to the one now in use at East Gate. Further insight should be gained into why the winds have differed between the two sites. The differences in winds as measured by the new propeller system and the orthogonal U.V system previously used will also be investigated.

The overprediction of daytime radiation levels will be investigated further. It is crucial to determine the amount of radionuclides that are mixcd down into the Los Alamos Canyon in transport. Therefore, a PIC may also be placed at the bottom of the Los Alamos Canyon to see if photon radiation is present because of the LAMPF plume. An additional PIC may be placed to the east of
I.AMPF at a distance of $500-1000 \mathrm{~m}$. Wind roses show that westerly winds occur frequently enough in the afternoon to give usable data. The canyon effect on diffusing radionuclides can be examined by comparing radioactive levels resulting from transport over the mesa with transport over the canyon. In addition, different methods for calculating the dispersion parameters $\sigma_{y}$ and $\sigma_{z}$ will be considered for the very slable cases of light nighuime winds along with the very unstable cases of light daytime winds. We hops that other methods will improve the representativeness of these variables during times of extreme stabilitics. Other po"sible PIC locations for brief periods would be the Bayo Sewage Treatment Plant to the northcast of LAMPF and other locations along State Road 4. Differences in the winds between the two sites could be taken into account to give more accurate model results. A simple trajectory model, using winds from both sites, should be used to better estimate winds across the canyon. Finally, other ways will be looked at to estimate and incorporate wind shear. A taller East Gate tower is recommended to give the best estimates of stack-level winds.

\section{ACKNOWLEDGMENTS}

We thank Jean Dewart (HSE-8) for her efforts in developing data processing software that made data acquisition possible and speedy, for her helpful suggestions, and for reviewing this report. We also thank Rudy Garcia for his hard work in computer programming and data processing while working with HSE-8 during 1985. Thanks also go to Thomas Buhl, HSE-8 Section Leader for Survcillance, for his encouragement and for revicwing this report. Thomas Gunderson, HSE-8 Group Lcader, has also helped us with his suggestions on the report and with his support. We appreciate the efforts of Daniel Talley (HSE-8) to provide the TLD data. We are thankful to Robert Dvorak for helping to provide the source term data, for his suggestions, and for revicwing the report. Kathy Derouin, with help from Gloria Brito, did the skillful and speedy job of preparing this document.

\section{REFERENCES}

Amcrican Socicty of Mechanical Engincers, "Recommended Guide for the Prediction of the Dispersion of Airborne Effluents," Third Edition, United Engineering Center (1979). 
B. M. Bowen, T. E. Buhl, J. M. Dewart, W. R. Hansen, D. Talley, I. Chen, W. A. Olsen, and D. M. Van Euten, "Measurements and Modeling of Gamma Absorbed Doses Due to Releases from a Lincar Proton Accelerator: Experimental Design and Preliminary Results," Procecdings of Furth DOE Environmental Protection Information Meeting, December 7-9, 1982, pp. 447-456.

G. A. Briggs, "Plume Rise," Atomic Encrgy Commission Critical Revicw Serics T1D25075 (1969).

R. R. Draxlcr," Determination of Atmospheric Diffusion Paramelers," Atmos. Environ. 10: 99-105 (1976).

Environmental Survcillance Group, "Environmental Surveillance at Los Alamos During 1984," Los Alamos National Laboratory report LA-10421-ENV (April 1985).
Environmental Surveillance Group, "Environmental Surveillance at Los Alamos During 1985," Los Alamos National Laboratory report LA-10721-ENV (April 1986).

J. W. Healy and R. E. Baker, "Radioactive Cloud Dose Calculations," in Meteorology' and Alomic Energy. US Atomic Energy Commission (1968).

U.S. Environmental Protection Agency, "National Emission Standard for Radionuclide Emissions from Department of Energy Facilities," Code of Federal Regulations, Title 40, Part 61, Subpart H (1985).

D. M. Van Etten and W. A. Olsen: "Improvement of a Portable Pressurized Ionization Chamber with the Addition of a Microprocessor Datalogger," Los Alamos National Laboratory report LA-1 10I4-MS (1987). 